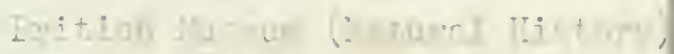
Ley. t. of wowions

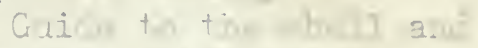
aterith culforito 


\title{
GUIDE
}

TO 'THE

\section{SHELL AND STARFISH}

\section{GALLERIES}

(MOLLUSCA, ECHINODERMATA, VERMES)

\author{
IN THE
}

DEPARTMENT OF ZOOLOGY

OF TIIE

BRITISH MUSEUM (NATURAL HISTORY), CROMWET工, ROAD, IONDON, S.W.

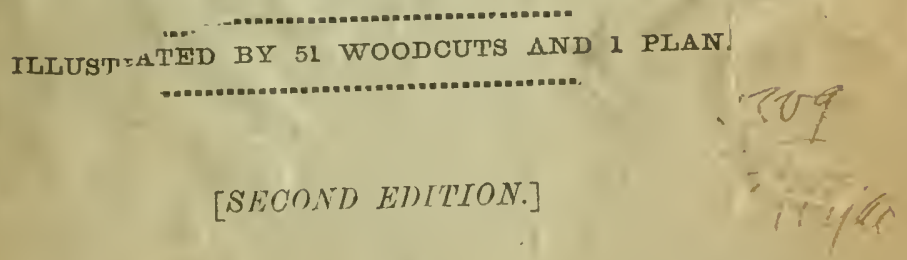

PRINTED BY ORDER OF THE TRUSTEES.

1888. 

Mollusca

B

\section{$G \cup \mid D E$}

TO THE

\section{SHELL AND STARFISH \\ GA工工ERIFS}

(MOLLUSCA, ECHINODERMATA, VERMES)

IN THE

DEPARTMEN OF ZOOLOGY

OF TIIE

\section{BRITISH MUSEUM (NATURAL HISTORY).}

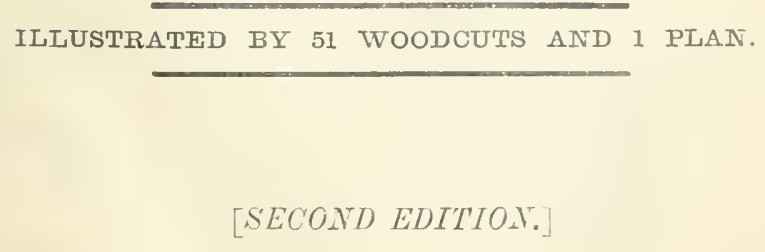

PRINTED BI ORDER OF THE TRLSTEES. 


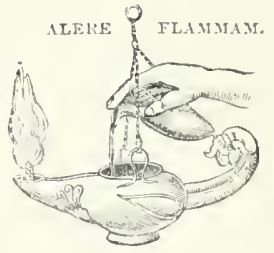

PRINTED BY TAYLOR AND FRANCIS,

RED LION COUIRT, FLEET STREET.

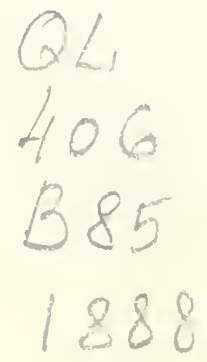




\section{PREFACE.}

ONe of the large side-galleries approached from the Bird Gallery is devoted to the exhibition of the extensive Class of Mollusca. Specimens of the types of all the principal divisions of this Class are exhibited, either entire and preserved in spirit, or as models. However, as not the animals, but their shells have always been a favourite object of study, and a popular source of pleasure tr collectors, the exhibition of the species of shells has been made as complete as the space of this Gallery admitted. It has thus proved adequate for the requirements of the majority of visitors who consult this Collection.

The Starfish Gallery, so called from one of the best-known types of the Echinodermata, contains an exhibition of the animals of this Class, as well as of the somewhat heterogeneous assemblage of creatures which are comprised under the popular name of Worms (Vermes). These animals possess greater attraction to students of Natural History than to the general public, and many, from their small size or the soft nature of their body, are not fit for exhibition. Therefore no attempt has becn made to show more than a 
carcfully selected number of the types of the larger groups. But the exhibition of very complete series, supplemented by models or figures, to illustrate the remarkable life-history of some of these animals, also of specimens of the Worms which possess a special interest from their relation to man, render this Gallery particuiarly instructive to the student.

In the preparation of this Guide I have received much assistance from Mr. E. A. Suith and Mr. F. J. Bell, the Assistants in charge of these Collections.

\author{
ALBERT GÜNTHER, \\ Keeper of the Department of Zoology.
}

British Mluseum, N. H., A pril 14, 1807.

\title{
TO THE SECOND EDITION.
}

The present (second) issue of this 'Guide' is a reprint of the first, with scarcely any alterations.

ALBERT GÜNTHER.

liritish Museum, N. II.,

March I, 18-5. 


\section{T.ABLE OF CONTENTS.}

THE SHELL GALLERY.

General Notes on Mollusea . . . . . . . . . . . 1

Their Systematic Arrangement . . . . . . . . . . $;$

Cephalopoda (Octopus, Cuttlefish, Se.) . . . . . 8

Pteropoda . . . . . . . . . . . . 13

Gastropoda (Shells, Suails, kc.) . . . . . . . 11

Scaphopoda (Tooth-shells) . . . . . . . . 32

Pelecypoda (or Bivalves, Oyster's, ke.) . . . . . . 33

General Notes on Brachiopoda . . . . . . . . . . 17

Alphabetical Index of Genera of Mollusea. . . . . . . 19

THE STARFISH G.ILLERY.

General Notes on Lehinorlermata . . . . . . . . -3

Crinoidea . . . . . . . . . . . . $6(6)$

Asteroidea (Starfishes) . . . . . . . . . . 61

Ophiuroidea (Brittle-stars) . . . . . . . . . . 61

Echinoidea (Sea-Urehins) . . . . . . . . . . 0.2

IIolothuroidea (Sea-Cucumbers) . . . . . . . . (i:2

Gencral Notes un Vermes . . . . . . . . . . . (j;)

Platyhelminthes (Tapeworms, Flukes) . . . . . . (6:)

Nematodes (Round-Worms, Triehina, \&c.) . . . . (6.)

Annulata (Marine Worms, Earthworms, Leeches) . . (is) 
Digitized by the Internet Archive in 2008 with funding from Microsoft Corporation 


\section{THE SHELL GALLERY.}

\section{GENERAL NOTES ON MOLLUSCA.}

The Molnusca constitute one of the principal divisions of the Animal Kingdom, and include such animals as the Octopus, Cuttlefish, Suail, Slug, Whelk, Cockle, and Oyster.

They may be eharacterized as soft cold-blooded animals, without Definidistinctly marlied external division into segments (as in Worms); their cerebral ganglia lie above the commencement of the vesophat gus, and are connected with the inferior ganglia by nerve-chords. 'Their heart consists of two or more chambers, and is situated on the dorsal side of the animal; it drives the blood into spaces between the various organs of the body. Only the Cephalopods possess internal cartilages, but all are without an osseous endo-skeleton; in the majority this is compensated by an external hardened shell which is formed (secreted) by the outer corering of the animal termed the mantle. 'The shell may consist of two parts (valves), as in the Oyster, or may be single, as in the Limpet, or composed of a The shell. series of plates, as in the "Coat-of-mail" sheils or" Chitons: when well developed it is hardened by a rich deposit of carbonate of lime; but it may be grelatinous, as in Cymbulia, or altogether absent, as in Octopus; it may invest the body, as in the Oyster, lie within the folds of the mantle, as in the Sea-hares (Aplysia), 
or it may be quite internal, as in the horny pen of the Squid. It may be elongated, as in the Elephant Tooth-shell (Dentaiium), cup-shaped, as in the Limpet, or spirally twisted on itself, as in the Snail.

Description of the animal.

The mantle may form a free fold on either side of the body, or it may become largely attached to the body-wall, as in the Snail or the Slug, and so give rise to an ail-chamber, which, when its walls are richly supplied with blood, serves as a lung. The ventral surfaee of Mollusks is produced into the so-called "foot," which may be very varionsly modified. The foot may be more or less hatchetshaped, or curved and capable of serving as a leaping-organ, or sole-shaped and adapted for ereeping; its margins may be prodnced into elongated processes, as the so-called arms of the Oetopus, eight in number and provided with suckers. or of the Nautilus, where the arms are much more numerous, but shorter and without suckers. In the Cephalopods, also, another part of the foot may fold over from either side and form a median funnel, through which the water of respiration is driven outwards, causing the animal to move in the opposite direction-this part of the foot having, therefore, still the function of an organ of locomotion. $\mathrm{By}$ means of their musenlar foot the Solenida, or Razor-shells, burrow in the sand, the Pond-Snails (Limnaide) crawl on aquatic plants and swim reversed on the surface of the water, the Limpet clings to the rock, and the Coekles and Trigonias take surprising leaps. The oper- Upon the upper surface of the foot, in many Gastropods, a flat
culum. hard structure termed the operculum is situated, which, when the animal is retracted, partly or entirely closes the aperture of the shell. In some cases, as in the Turbos, the operculum is rery strong and of a stony nature, but in most instances it is horny. It is differently constructed in distinct families: it may be annular and nultispiral, annular and pancispiral, subannular and ovate, or subannular and unguiculate. In Nerites it is shelly, somewhat semicircular, closes the aperture of the shell, and is furnished with a stont projection on the straight edge, fitting like a hinge under the inner lip of the shell. A series of opercula is exhibited in

The

breathi 2 g-orrans, Table-case G.

Thread-like processes on either side of the body, the so-called gill-filaments, often unite with those in front of and behind them, 
and so give rise to plates; these, when well developed, are best seen in the division to which the Oyster and the Mnssel belong, and which, therefore, las been ealled the division of the plategilled Molinsks, or Lamollibranchiata, but now called Pelecypoda. Where the body is coiled or twisted on itself, as so often happens, the grills of one side may be altogether lost. Sometimes, as in Phyllirhö, when the body is small and its wall thin, the gills disappear altogether, and there is no special breathing-organ; in others the loss of the gill is eompensated by the formation by the mantle of a lung; this is most often seen in the forms that live on land.

But these so-ealled gills may have other functions: in the Peleeypods, where there is no head and no special means by which the creaturc can obtain food, the delicate waving filaments or ciliu with which they are covered cause currents in the surrounding water, by means of which minute organisms are brought to the mouth.

All Mollusks, except the Pelecypods, have a very remarkable structure developed in the floor of their mouth-cavities; on a The odontophore. basis of cartilage, which may be moved backwards and forwards by muscles, there is developed a stout horuy plate, which may be of considerable length, and which has its upper surface covered with a number of more or less fine, flattened, or spiny outgrowths, which are known as teeth. This is the odontophore, tongne, or ralula (see fig. 12).

Eyes may be absent, as in the headless Pelecypods; but in the The eyes. rest they are generally present, and may be more or less well developed. An instructive series of stages is exhibited by the Cephalopoda. In Nautilus the eye remains an open pit; in Ommatostrephes two chambers appear, the anterior of which is bounded posteriorly by the leus, and is open to the exterior, so that sea-water enters it; in Sepia, finally, the anterior chamber becomes closed in front. We may observe that the eyes of all Cephalopods are at first pit-like, or pass through a stage which is permanent in Nautilus, one of the geologically oldest types.

Eyes of a more complicated strueture, which arc modified tentacles, are sometimes found on the edges of the mantle in Pelecypods (e. g. Pecten); these eyes resemble those of Vertebrates, and differ from those of nost invertebrate animals in having the 
fitres of the optic nerve entering the distal and not the proximal einds of the retinal cells. Eyes of a similar construction are to be found on the back of the sheli-less Oncidium, and may be about one hundred in numiber.

Quite recently eyes of a remarkable character have been deteeted by Professor Moseley on the shells of some of the Chitons; they appear to be modified from tactile organs, and are innervated like the ordinary mollusean eye; they are perhaps most remarkable from their enormous number, more than ten thousand being present on one animal (see wax-model, Case 12 c).

Organ of hearing.

Sense of smell.

In Cephalopods the ear', like the eye, is known to make its first appearance in the form of an open pit, the mouth of which gradually closes up, leaving only a narrow slit in communication with the exterior. It is probable that in many forms the socalled ear is an organ by means of which the mollusk becomes acquainted with changes in the surface over which it is passing; it is often found deeply imbedded in the substance of the foot, where it forms a closed vesicle.

There is no doubt that the carnivorous Gastropoda are grifted with a sense of smell, and throughout the series we observe patches of modified cells of the body-wall which serve either as olfactory organs or as an apparatus for testing the nature of the water of respiration.

The sexes The sexes are distinct in the most highly organized Mollusca, and repro- but are united in the same individual in some of the lower forms,
duction. such as Land-Snails, the Opisthobranchiata (including the BubbleShells, Sea-Slugs, \&c.), and in some Bivalves. The reproduction of Mollusca is in all eases effeeted by means of eggrs. In some instances the young are actually hatched within the oviduct of the parent, as in the Freshwater Snails (Paludina); and apparently in most Bivalves the eggs are also retained within the valves until hatched.

The ova of many mollusks are deposited in masses enclosed in capsules. Some of them are very wonderful and complicated structures. 'Those of the Cuttles and their allies are clustered like grapes, cach capsule containing but a single embryo; but in the Calanaries or Squids they form a radiating mass of elongated sacks, each containing from thirty to two hundred egros, and it 
has been estimated that one of the spawn-chusters of the Common Squid (Loligo rulgaris) contains as many as 40,000 ova. Everybody knows the spawn-cases of the Common W'helk, found so abumdantly on the sea-beach, consisting of a large number of yellowish capsules, heaped one mpon another and forming an irregularly rominded mass. As many as five or six hundred capsules may be piled together in a single heap, each capsule containing screral hundred eggs, of which, however, perhaps only thirty or forty are hatched.

In other families, as Aplysia, Doris, Eolis, \&c., the crgors are contained in a spirally rolled ribbon or strap-like structure; and some of the Nutice build a somewhat similar capsule, conpused of the egres cemented together by sand and a gelatinous material, the whole forming two thirds of a circle narrowed at the upper part.

Terrestrial Molluskis deposit, in eomparison with their narine relations, but very few egors. 'They are sometimes covered by a thin soft skin, but in certain groups, such as the large SonthAmerican Bulimi and the African Achatince, which include the largest of known land-mollusks, they are protected by a hardened calcarcous shell, in some instances fully an inch in dianetcr. The fieshwater forms (Limnaa and Physa) deposit from thirty to a humrired eggs enveloped in a gelatinous mass.

The number of exgs produced by some Bivalves is enormous. The Common Oyster is said to produce a million or more, and the Americau variety ten, or even sixty, times as many. Some of the River-Mussels are also very prolific, as many as two millions being sometimes the product of a singie individual. A small series of the eggs of Land-Suails and of the cgo-capsules of some mane (rastropods is exhibited in Table-case Gr near the entrance to the Gallery.

The ova of Mollusca may be gradually developed into the form of the parent, or there may be a frec-swimming lara, which has a circlet of cilia near the anterior pole of its body (so-called "Veliger" larve), or there may be special larve, as in the case of the Freshwater Mussel, the "Glochidium" as it is called, which has a toothed bivalve shell by which it can fix itself to fishcs.

The limits of age of mollusks has been definitely ascertained in a few instances only. Most Land-Snails probably live about two of life. years, although in confinement some have been kept alive for a 
much longer time. Some of the marine forms live for a considerable period, the Common Oyster not attaining full-growth until about five years old, after which it may continue to live for many years. The Giant Clam, a specimen of which is placed on the floor near the entrance to the Gallery, must, one would think, have a very long existence, judging from the size and thickness of the shell.

Itibernation and torpidity. All terrestrial mollusks hibernate in cold elimates, hiding themselves away in the ground between roots and similar sheltered places. In tropical countries some assume a state of torpidity (iestivate) during the hottest and driest season of the year, closing up the aperture of their shells with a temporary lid or door (epiphragin), in order to resist the dryness of the atmosphere. Some of these "summersleepers" are endowed witl a remarkable tenacity of life. An Australian Pond-Mussel has been known to live a year after being remored from the water; several Land-Snails have revived after a captivity of from two to five year's, without any food whatever. One of the most remarkable instances of this kind occurred in the British Museum. A specimen of Helix desertorum, a common Desert-Snail from Egypt, was fixed to a tablet in March 18t6, and in the same month of the year 1850 it was discovered to be alive. It must have come out of its shell in the interval, and finding it was unable to crawl away, had again retired within it, closing the aperture with a new epiphragm, but leaving traces of slime upon the tablet, which led to its immersion in water and subsequent revival, having passed a period of four years in a dry museum without the smallest particle of food.

Eccnomic The economic uses of nollusks to man are manifold, and will be uses. mentioned in the course of the description of the several families; but here may be the place to direct the attention of visitors to Table-cases $\mathrm{E} \& \mathrm{H}$ near the entranee of the room, containing some specimens of articles manufactured from shells, such as cameos, flowers, bracelets, brooches, \&c.

Creological Mollusea made their appearance on the globe at a very early history. epoch in the history of the development of animal life, a large number of fossil forms, such as Nautilus, Lituites, Orthoceras, \&c., being found in the oldest Palrozoic formations. Probably all these belonged to the Tetrabranchiata, of which one descendant only, the Pearly Nautilus, has survived to our period. Some Gastropods 
and Bivalies cocxisted with those ancient Tetrabranchiates; but these types abounded more in the later geological epochs, many 'Tertiary forms being undistinguishable from species which now exist.

The greater number of Mollusea are inhabitants of the sca, some passing their whole life at the surface hundreds or thousands of miles away from land; others at the bottom of the ocean at all depths, some having been dredged at five miles from the surfice. Nany are found in much shallower water, and a large number between tide-marks. Rivers and lakes furnish an immense varicty of forms, and vast numbers live on land in all situations-on monntains, in valleys, forests, and deserts.

Mollusks are either animal- or vegretable-feeders, the former preying principally upon other members of their own class.

The subjoined Table shows the systematic arrangement of the systeMollusea adopted in the Shell Gallery:-

\section{Class I. CEPHALOPODA.}

Subclass I. DIBF৯NCHI\TA.

Pages

Order 1. Octopona: Octopus or l'oulp and Argonaut ..

2. Decapona: Squids and Cuttlefisles......... $10-12$

Subclass II. TETRABRANCHIATג.

Natritides: Pearly Nautilus.

$1: 2,1: 3$

\section{Class II. PTEROPODA.}

Order' 1. 'T'hecosonata: Cavolina, Cymbulia, Limacina.

2. Grmasosomata: Clio, Enribie

\section{Class III. GASTROPODA.}

Subelass I. PROSOIBRANCIIITA.

Order 1. Prctinemranchiata: Rock-Snails, Whellis, Oives, Harp-shells, Cones, Strombs or Wingshells, Periwinliles, Carrier-shells, Ne. .....

2. Scutibranchita: Nerites, Top-shells, Garshells, and Limpets $\ldots \ldots \ldots \ldots \ldots \ldots \ldots$ 2.9.2.5

3. Polyplacophora: ('hitolls .......... 2.

Giner::l distribution. 
('lass III. GASTROPODA (contimued).

Subclass II. OPISTHOBRANCHIATA.

Order 1. Tectibraxchita: Bubble-shells, Sea-Hares, Umbrella-shells ............. 27, 28

2. Nidibraxchita: Sea-Lemons (Doris), \&c. . 28

Subclass III. NUCLEOBRANCHIATA (or HETEROPODA).

Firolas, Carinarias, Atlantas $\ldots \ldots \ldots \ldots$. . .

Subclass IV. PLLMONATA.

Order 1. Struomatophora: Sings, Snails ....... 30,31

2. Basomatopiora: Water-Snails, False Limpets 31,32

Class IV. SCAPHOPODA: Tooth-shells (Dentalium) ........ 32

C'lass V. PELECYPODA (or LAMELIIBRANCHIATA).

Order 1. Siphoxids: Clam-shells, Cockles, Tellens, Tredge-shells, Gapers, Razor-shells, Piddocks, Wateringpot-shells, ifc. ..........

2. Asiphorid : Orsters, Scallops, Pearl-Orsters,

Inussels, Arks, River-Mussels, \&c. ...... $40-46$

\section{CEPHATOPODA*.}

Case 1, This Class includes the Octopus, Cuttlefish, Squid, Spirula, the A-D.J Paper and Pearly Nautilus. The body of the animal consists of a muscular sac, in the cavity of which the viscera are placed. In front of the body projects the liead, which, in species belonging to the two-gilled section of the Class, is surrounded by eight or ten fleshy arms. A wide aperture below the head admits the water to the gills or branchire, which are situated in the interior of the sac, whilst a short tube, the so-called funnel or siphuncle, projects from the opening of the mantle-the water and various excretions being expelled through this tube, especially also an ink-like fluid, which is discharged by all Cephalopods (except Nautilus) when disturbed, in order to darlien the water and thus escape their enemies. The centre of the head, between the base of the arms, is occupied by the mouth, which is armed with tro horny or calcareous jaws, similar to the beak of a parrot. The two large eyes are placed on

* From the Greek : Fephale, head, and pous, foot. 
the sides of the head. The arms or feet are more or less clongate, capable of mosement in any direction, and, execpt in Nautilus, furnished on one side with numerous suekers, by means of which the animal attaehes itself most scemrely to anything it may scize; they are employed in capturing food and in walking. Cephalopods walk in any direction head downwards, but can swim backwards only, being propelled in that direction by the water which they discharge with force through the funnel ont of their branehial eavity. They are divided, according to the number of

Fig. 1.

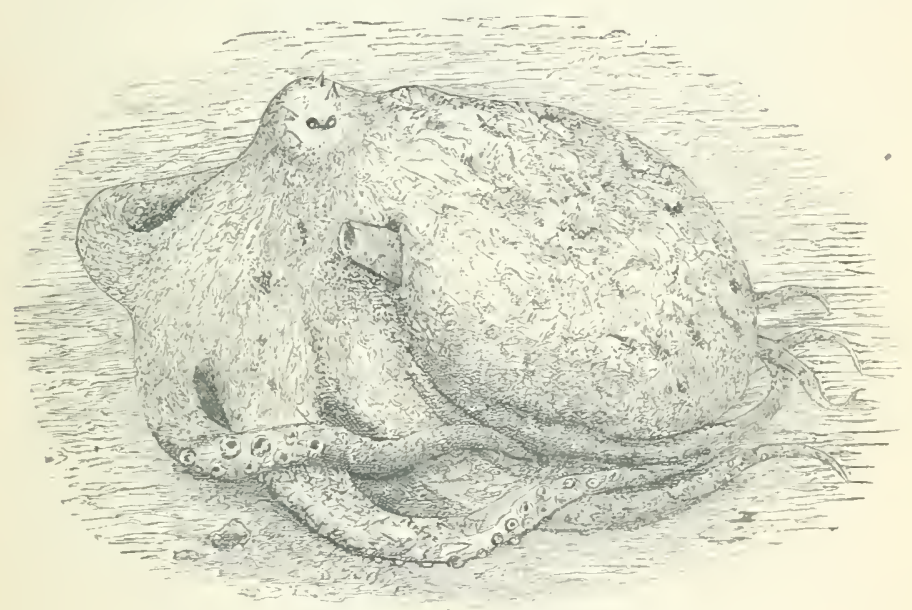

The Common Octopus (Octopus vulgar is), resting.

their gills (which is either two or four), into Dibranchiata and Tetrabranchiatı. Of the latter but one represcntative now cxists, viz. the Pearly Nautilus, all other living Cephalopods being provided with but two gills, placed one on each side of the body within the mantle, as may be scen in the wax model of Sepia officinalis (Case $1 \mathrm{c}$ ). The two-gilled seetion comprises forms with eight arms, as Argoncuta and Octopus, and others with ten alms, viz. the Cuttlefishes (Sepia) (fig. 2), the Squids (Loligo, Ommatostrephes, \&e.), and Spirula. The "shell" of the Paper- 
Nautilus, or Argonauta, is too well known to require any description. Unlike the shells of other Mollusea, it is not attached to the animal by a special muscle, but is held on to the body by two of the arms, which are dilated and specially adapted for this purpose. Only the female Argonaut is provided with a shell, the male being shell-less and a much smaller creature. The Argonaut-shell is therefore not a true shell, but simply a reeeptacle for the ova, serving at the same time for the protection of the parent.

The species of Octopus are found on the shores of almost all temperate and tropical seas; they do not attain to a large size, and are without the internal shell or "bone" whieh is found in the mantle of many Cephalopods. That of the Cuttlefish or Sepia (fig: 2 a) is found in abundance on our coasts; it is composed of numberless layer's of a friable calcareons substance. 'That of the Squid tribe is of quite another eharacter, consisting of an elongate thin horny plate, and strengthened by one or more thickened ribs, in some species somewhat resembling a quill-pen. Some species of this pen-bearing class related to the Common Squid attain an immense size. One was eaptured off the Irish coast in June 1875 (probabiy Architeutlis harveyi) with the shorter arms 8 feet in length and 15 inches in circumference at the base, the two tentacular armis haring a total length of 30 feet. The powerful beak measured ahout 4 inches across. Thus from the tip of the tail to the end of the tentacular arms this wonderful mouster must have measured something like 40 feet in length. Other very large specimens of Architeuthis have been captured on the coasts of Newfoundland and Labrador. Two specimens stranded on the south coast of Newfoundland, in the winter of 1870-1871, measured respectively 40 and 47 feet. Another, cast ashore at Bonavista Bay in December 1873, had a very stout borly $1+$ feet long, arms 10 feet, and tentacles 24 feet in length. Those are ouly a few of the many instances of the capture of gigantic Cephalopods, which occur not only in the North-Atlantic Ocean, but also in tropical seas. Their appearance in mid-ocean may, in some instances, have given rise to the tales of "Sea-serpents." Specimens much smaller than those mentioned ahove have attacked men, and pearl-fishers are in constant fear of them. One of the arms of a large Squid (Architeuthis harveyi?), which is supposed to have been found off the coast of Sonth America, 
Fir. ‥
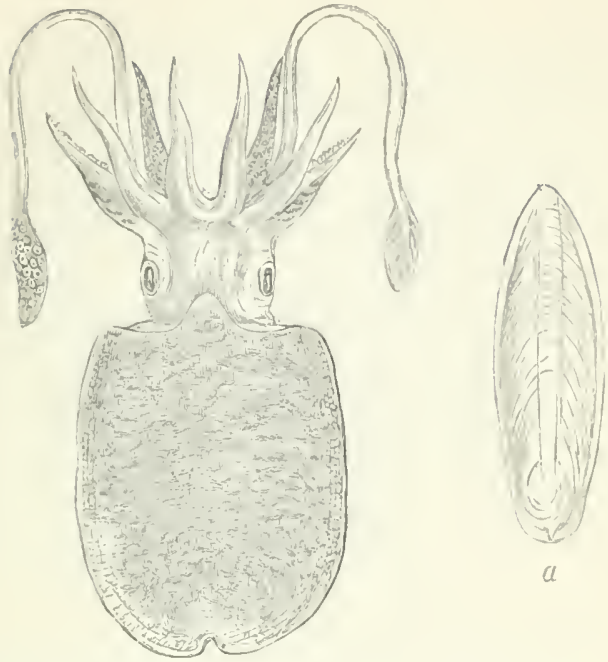

The Comm on Cuttlefish (Sepia officinalis), and its shell or bone (a).

Fiי. 3.
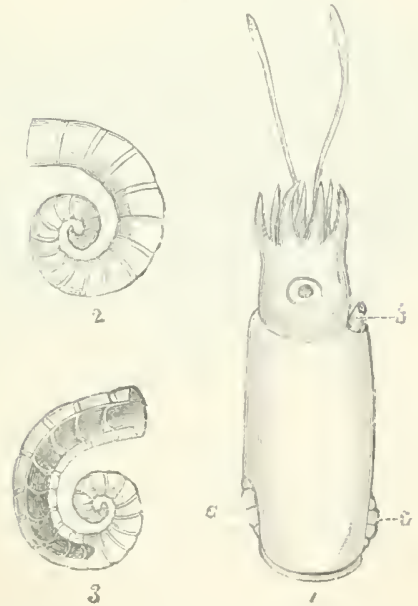

The Spinda (Spirula peronii). (From the Indian and Pacific Oceaus.)

1. Inimal: $a$, portions of the shell exposed in front and behind; $b$, the fumnel or siphuncle. 2. Side riew of shell. 3. Shell in section, to show partitions or septa. 
is exhibited in the upright Case A ncar the entrance to the room.

The shells of Spirula (fig. 3) have been long known, and are scattered in thousands on the shores of New Zealand ard other islands in the Pacific Ocean, and they are also found in the Indian and Atlantic Oceans, occasionally drifting on the coasts of Devon and Cornwall. Notwithstanding the abundance of the shells, very few specimens of the perfect animal have been captured. The looselycoiled shell resembles a ram's horn, and is divided into a number of segments by fine concave partitions, like the shell of Nautilus, each one pierced by a slender tube or siphon. It is placed at the hinder end of the body, and, although usually spoken of as internal, is not in reality wholly so, as a small portion of it is exposed both in front and behind. Absolutely nothing is known of the habits of this very interesting creature, although probably they are similar to those of other Cephalopods.

The Nautilus (fig. 4), of which several shells and a perfect animal

Fig. 4.

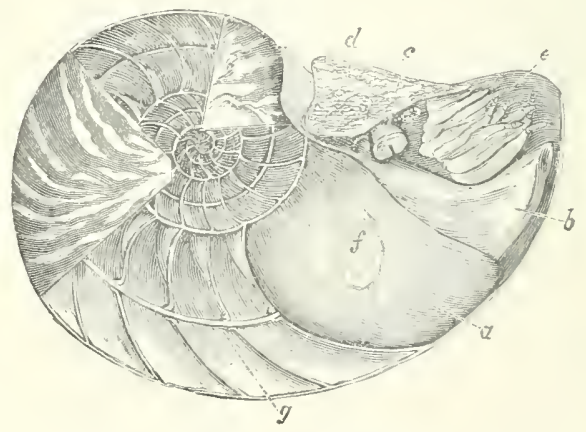

The Pearly Nautihs (Toutilus pompilius).

$a$, body ; $b$, siphuncle; $c$, eye ; $d$, hood : $e$, tentacles : $f$, muscle of attachment to the shell; $g$, siphon.

in spirit are exhibited, is an inhabitant of the Indo-Pacific Ocean, and differs from all other living Cephalopods in being prorided with four instead of two gills, and, instead of eight or ten arms with suckers and hooks, has a number of small retractile feeler. 
The Nautilns occasionally swims, like other nembers of its class, at the surface of the sea, but mostly crawls about leisurely on its feet at the bottom in seareh of food, which consists chicfly of small crabs or Mollusca, which it crushes with its strong calcarcous parrot-like mandibles.

The chambered shell is pearly within, and covered with an external ealearcons layer. The chambers are connected by a slender tube or siphon, the function of which is not at present thoroughly understood. The septa, or partitions across the shell, indicate periods of growth. When the Nautilus outgrows the capacity of the outer chamber, in which it resides, it constructs a new one of larger size, separating the additional chamber from the preceding one by a transverse partition.

\section{PTEROPODL*.}

The Pteropods are sometimes called Sea-butterflies, and, like the [Case $1 \mathrm{E.}$ ] preceding group (Cephalopods), are organized for swimming freely

Fig. 5.
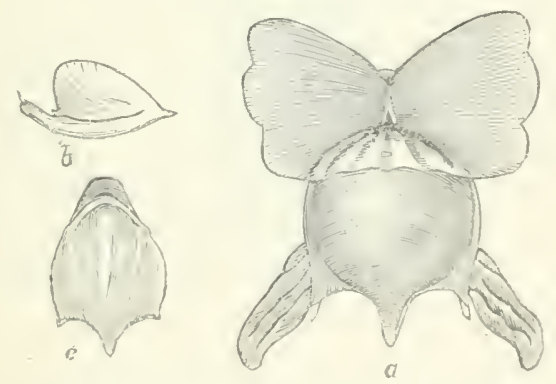

Shell-bearing Pteropod (Curvina tridentata).

$a$. Shell and animal. b. Side riew of shell. c. Dursal view of shell.

in the ocean. They have a pair of fins dereloped from the sides of the mouth or neck, which perform a flapping morement during progression. Some Pteropods (Thecosomata) are provided rrith

* From the Greek: pieron, wing, and pous, foot. 
small glassy shells; others (Gymmosomata) are naked. They exist in countless millions in some parts of the ocean, discolouring the

Fig. 6.

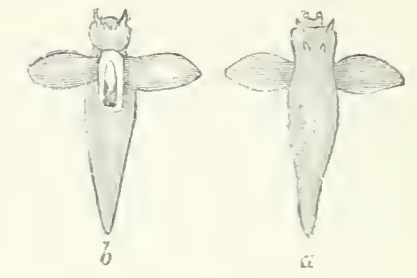

Sheli-less Pteropod (Clio borealis).

a. Dorsal riew. b. Ventral aspect.

water for miles. They constitute the principal food of the Baleen Thales.

About a hundred species are known.

TCaces $1 \mathrm{E}-17 \mathrm{D}$.

\section{GASTROPGDA*}

As is indicated by their name, the mollusks of this class crawl or glide on the under surface of their body, termed the "foot." They have been divided into four sections:-1. The Prosobranchs, which have the gills situated behind the lead in advance of the heart, and are always provided with a shell. 2. The Opisthobranchs, in which the position and structure of the gills are variable, but always behind the heart, and in which the body is either naked or with the gills protected by a shell, which is external or concealed in the mantle. 3. The Nucleobranchs, which have the gills in a tuft at the hinder part of the back, in some cases protected by a shell; they do not crawl like the ordinary Gastropods, but are found swimming freely in the open sea, like the Pteropods. 4. The Pulmonata or air-breathers, the breathing-cavity of which opens only by a small aperture, which can be closed by a valie. These four primary divisions of Gastropods have beer variously split up into smaller sections-families, genera, and subgenera; the more interesting will be pointed out in the following pages.

* From the Greek: gaster, belly, and pous, foot. 


\section{Prosobraxchitata.}

The Conida, or Cones, form one of the most beautiful portions of [Case 1, the collection of Shells. This family, of which about 100 distinet E-11.] kinds are known, is a great favourite with collectors on account of the brilliant colours and various patterns of the shells. Some,

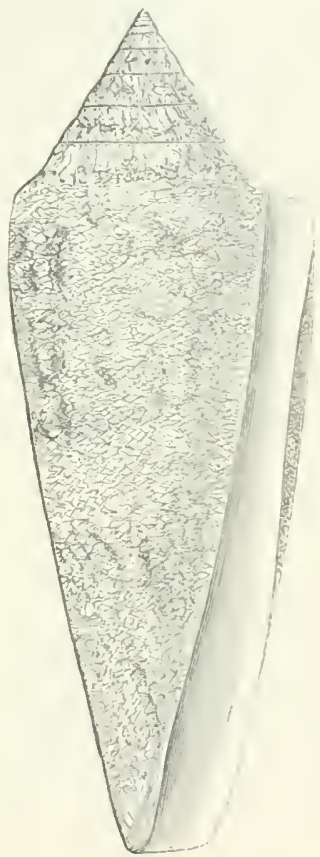

The "Glory-of-the-Sea" ('one (Conus" gloriu-maris). (From the Philippine Islands.)

owing to their beauty and rarity, have been sold at very high prices, as much as $£ \check{0} 0$ having been paid for a single shell. The Concs are found in all tropical seas, but are rare in cold or temperate latitudes. None are met with on our own shores, one species alone being known from the Mediterranean. They occur fossil in the Chalk and Tertiary strata. These animals are all carnivorous, 
and live usually in shallow water among rocks and coral-reefs. Some of them are said to bite when handled, and to be dangerously poisonous, the bite in some instances having been all but fatal.

[Case 2, The "Auger-shells" (Terebride), like the Cones, present a great A-C.] similarity in form, but, unlike them, have a great diversity of "sculpture" or external ornamentation. They are all elongate shells, with a deep notch at the base of the aperture. Owing to the length and comparative solidity of the shells, the animals of many of the species do not carry their shelly structures on their backs, like most other species, but drag them along the sandy sea-bottom.

「Case 2, $\mathrm{C}-\mathrm{E}$.

Cases $[\mathrm{E}-3 \mathrm{~F}$.

The next family, the "Slit-lips" (Pleurotomatide), consists of very numerous species, over a thousand living forms haring been discovered, and almost as many fossil species from Cretaceous and Tertiary strata have been described. The typical forms are characterized by a slit in the outer side (lip) of the aperture. Species of Pleurotoma are found in every sea, although most abundant in the tropics, and, although so numerous in species, the number of specimens is small in comparison with some other genera.

The family of Muricidce, or "Rock-shells," is another extensive group, containing many very landsome and peculiar forms. The animals of this family have a long proboscis, at the end of which is the spiny tongue (odontophore), and which is retractile within the body. The true Murices produce at intervals ribs or varices, which in some species are ormamented with long spines or foliations, and which indicate periods of growth, but of what duration we do not know. They are all carnivorous, feeding chiefly on other Mollusca, boring through the shells of biralves with their spiny tongue, and slowly devouring the unfortunate inlabitant piecemeal. From certain species of Murex (M. Lrandaris, Sc.), found in the Mediterranean, the ancients manufactured the celebrated Tyrian purple dye.

The family of Buccinidee also contains a very large and various assemblage of forms. Among them may be mentioned the Whelks (Buccimum) and the "Purples" (Purpura), found betreen tidemarks all over the world. Magilus is found among coral-reefs in tropical seas, and has the remarkable habit of lengthening the 
aperture of its shell into an elongate tube, in order to keep pace with the growth of the coral, and to prevent its being overgrown and killed.

Fir.r.

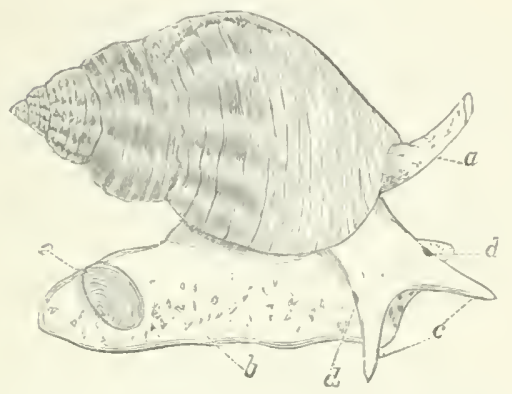

The Common Whelk (Buccinum undatum). $a$, siphon; $b$, foot; $c$, tentacles; $d$, eyes; $e$, operculum.

The Olives (Olividee) are common in most tropical seas, and are remarkable for their beautiful polish and various patterns of colourCase 4. 1) D.] ing. In structure and form they are very similar to each other. They burrow in sand in quest of bivalves for food, and some species are said to have the power of swimming by expanding the lobes of the foot.

The Harjs (Harpicle) form asmall well-marked group, of which probably all the existing species have been discovered. The animals Case $t_{4}$ D-E.] inhabiting these beautiful shells are also brightly coloured. They have the remarkable power of casting off a portion of the foot when clisturbed. The species are known from the Indo-Pacific Ocean, the west coast of Central America, and West Africa.

The Fasciolariida contains one of the largest living Gastropods (Fasciolaria gigantea), which is found off the coast of South Carolina, C'ase 4 , and attains at times at length of two feet.

The Mitras (Mitridee) are great furourites with shell-collector's, on account of their beautiful colour's and varied seulpture. There are about 600 living species already known, and between one and two hundred have been found in a fossil state. Shells of this group, like the Fasciolario, are distinguished by a few plaits or folds on the imner side of the aperture (the columella). Mitras 
are almost exclusively found in tropical or subtropical regions, the majority being met with either at low-water mark or in comparatively shallow water.

ГCase 5, The "Volutes" (Volutide) are a group of shells also much C-F.] songht after by shell-collectors. Some of these attain to a very large size, the animals inhabiting them being enormous. The Boat-shells (Cymba) and Melons (Cymbium) are ovo-viviparous, the young being carried about by the prarent until they are an inch in length. Volutes are found chiefly in the warmer parts of the Atlantic and Indo-Pacific Oceans, and occur in the greatest variety on the coasts of Australia.

[Case 5, The "Helmet-shells" (Cassididce) are used for cameo-carring; C-H.] they consist of differently coloured layer's, so that the groundcolour of the carving is of a different tint from the subject engraved. The most artistic shell-cameos are produced in Italy, whence the art has been introduced into France and England. The Cassis madagascariensis is in special request by shell-carrers on account of the strong contrast of the white upper layer with the dark ground beneath. Extinct forms of Cassis are found fossil in Tertiary formations, but none of them equal in size the largest living species.

[Case 6, The "Tun-shells" (Doliidce) are remarkable for the globoseness A-D.] of the shells, which are covered with very regular revolving ribs.

The "Trumpet-sbells" (Tritonida) have varices or strengthening ribs at intervals, like the Muriees; the largest species, Triton variegatus, is used by South-Sea Islanders as a horn or trumpet. A hole is made in the upper part of the spire to blow through, and the somd produced ean be modnlated or varied by inserting the hand in the aperture or mouth of the shell.

[Case 6. This case contains the "Fig-shells" (Ficula), the Natica, the D-I.] "Violet Snails" (Ianthince), the "Wentle-traps" (Scalariida), and the Solariums or "Perspective-shells." The Naticas are mostly blind, and have a very large foot, suitable for burrowing in the sand when in quest of bivalves. They are very voracious. This is one of the groups of shells that have continued to exist from Palæozoic times.

The Scalaria pretiosa was formerly considered a great rarity, as much as $\mathfrak{E} 40$ having been given for a single specimen, which might now be purchased for as many pence. The "Violet Snails" 
are fonnd floating about in every ocean, with the spire of the shell downwards, and the bottom, being more exposed to the action of light, is more deeply tinted than the upper part. 'They feed upon Jelly-fish, and construet a gelatinons laft, filled with air-bubbles, beneath which the females attach their egg:s.

A large section of the Gastropods, commencing with the "AppleSnails" (Ampulleriidec) and ending with the "Carricl-shclls" (Phorida), are mostly vegetable-fecters, and, mnlike the preceding families, have a proboseis or snout, which is not retractile.

The "Apple-Snails" (Ampullariide) live in the river's and marshes of tropical regions, and, although represented by a large Case: $(j \mathrm{r}-7 \mathrm{i}, \mathrm{T}$. number of species, exhibit comparatively slight rariations in form and colour.

Of the Ovulide, the most eurious is the "Weaver's-shuttle" (Radius rolva), in which the shell is peculiarly beaked at both ends. It is found living on barked corals (Goryoniedce), and some of the smaller species exhibit differences of coloration, resembling the tints of the Gorgonias upon which they are found.

The "Cowry-shells" (Cypreidce) are remarkable for" their ("ase T, B-F.]

Fig. 9.

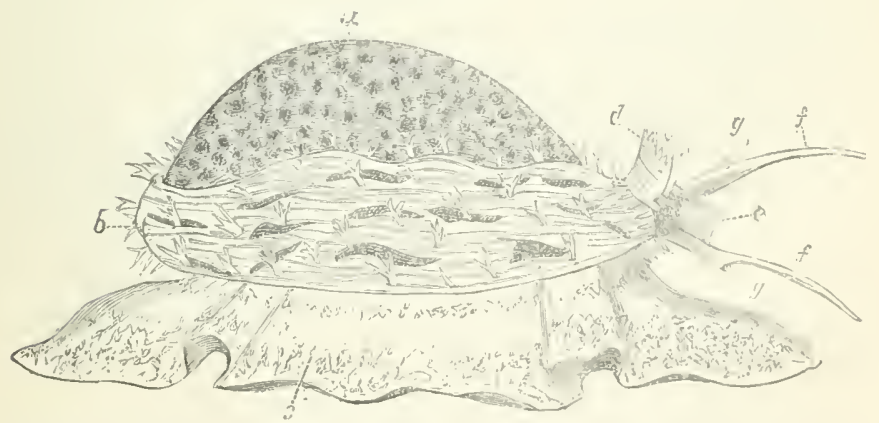

The Tiger Cowry (Cyprea tigris). (From the Indo-Pacific ()ean.) $a$, the shell; $b$, the mantle; $c$, foot; $d$, siphon; $e$, proboscis; ff, tentacles; \%, eyes.

varied markings and splendid polish, which is produced and preserved by two flaps of the mantle, one on cach side, which fold over the back, a line down the centre of which usually marks 
where the flaps meet. The animals are even more brilliantly coloured than the shells. They have no operculum, but a large foot, which they can withdraw entirely within their shell, although the aperture is usually very narrow. Cowries, as is well known, are sold as ormaments; and a small yellow species, "the moneycowry" (C. moneta), which is very common in the Indian and lacific Oceans, passes current as coin among the negro tribes of certain parts of Africa. The "orange cowry" (C. aurora) is worn by chiefs in the Friendly Islands, and is considered the highest order of dignity. Only one small species, C'. europaea, is found on the British coasts, and about 100 fossil forms have been discorered in the Chaik.

[Cases $7 \mathrm{E}-8 . \mathrm{A}$.

[Case : A - B.]

[Case s, $\mathrm{C}-\mathrm{F}$.

[Case 8 , G-H.

[C'ases ¿H - 9..?

The Cyclophoride and Helicinida are land-shells, which, however, cannot properly be considered true lung-breathers like ordinary Snails. They have not the closed lung-chamber of the Pulmonates, their eres are placed at the base of the tentacles instead of at their tips, they have a long proboscis armed with a different rasping tongue (odontophore), a spiral operculum, and the sexes are distinct, whereas the true Snails are hermaphrodite.

The operculated air-breathers have been dirided into many sections, chiefly on account of differences in the apertures of the shells and in the opercula. They most abound in hot countries, but a few species are met with in temperate regions.

The "Periwinkles" (Littorinida) are found almost on every known shore; they feed upon all kinds of marine vegetation. Some species are met with at low-water mark, others on rocks almost beyond the reach of the sea, and some have been discovered nearly half a mile away from the shore. It is calculated that 1900 tons of the "Common Periwinkle" (Littorina littorea), of the value of $\mathfrak{R} 15,000$, are annually consumed in London alone.

The Melaniide are freshwater snails which abound in most tropical and subtropical countries; about 1000 species are known. They are mostly of dark colours, and are fond of muddy places.

The Cerithiidce are chiefly marine forms, some, howerer, entering brackish water. About fire hundred fossil species have been described, some of them gigantic in comparison with any now living, of which more than two hundred are known.
The "Screw-shells" (Turritellide) have clongate tapering shells; 
about 100 recent and :200 fossil species are known. Onc species only (Turvitella communis) is now found living on the 13ritish coasts.

'The "River-Snails" (Puludinide) might be termed fresliwater" l'eriwinkles, as the animals of both are very similar. 'The true l'alulince are viviparous. They are rather shugrish, and found at

Fig. 10 .

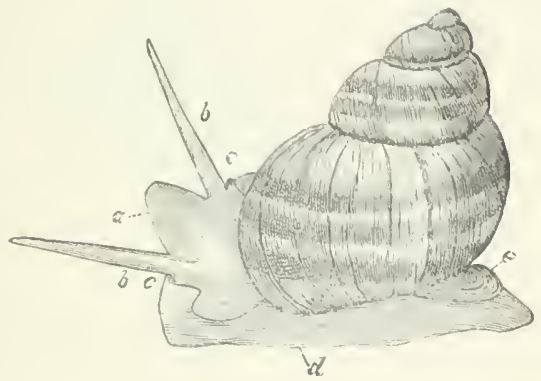

The Common British River-Snail (Paludina rivipara).

$a$, head; $b$, tentacles; c, eyes: $d$, foot; e, operculum.

the bottom of ponds and rivers feeding on decaying animal and vegetable matter.

The family of Culyptreidee includes the "Slipper-Limpets" (Crepidula) and the "Cup-and-saucer Limpets" (C'ricibulum). [Case 9, B-C.] Although furnished with a foot, they rarely crawl about, but remain attached to rocks, stones, or other shells, sometimes forming a shelly plate under the foot by which they become fixed to the spot where they hare taken up their abode.

The " 1 Torm-shells" (Termetide) are a rery peculiar family. Their shells can scarcely be distinguished from the shelly tubes [Case ?, D-E.] which are formed by certain species of marine worms, Serpula, \&c. They are free and spiral in early life, hut afterwards become distorted and generally attached to rocks, stomes, Sc. A foot for walking puposes therefore would be of no use; consequently it is more or less obsolete, serving only as a support to the operculum.

The " Wing-shells" (Strombide) are the largest of the Gastropods with a proboscis or non-retractile snout. 'They do not crawl like [Case 9, E-H.] most other Gastropods, but progress by a sort of hopping move- 
ment. They act as scarenger's, feeding on decomposing animal matter.

[Case 9r.] The Strombus gigas, or "Fountain-shell," occurs in great numbers in the West Indies, and is a very heavy solid shell. It is a favourite ornament for rockwork and fountains in grardens, and, like the Helmet-shells, is used for cameo-carring. It is also employed in the manufacture of porcelain, as many as 300,000 having been imported into Liverpool in one year for that purpose.

The Scorpion-shells or "Spider-claws," as they are sometimes called (Pterocera), possess singular claw-like projections, which are developed on the outer lip of the shells.

[Cases The Onusticle, with the genera Phorns and Onustus, have the $9 \mathrm{H}-10 \mathrm{~A}$.$] singular habit of cementing to the exterior of their shell, stones,$ pieces of coral, and fragments of other shells; henee they have been called "Carrier-shells," and, according to the kind of material chosen, hare been named "Conchologists" and "Mineralogists." Beyond acting as a disguise, and consequently as a protection, there does not appear to be any special utility in thus adding to the weight of their own shells. The animals do not glide like most other mollnsks, but scramble along like the Strombs, the form of their foot being small, divided into a front, expanded, and a hind tapering portion admirably adapted to the nature of thi ground on which they live, which nsually consists of broken and dead shells.

[Case 10, The Nerites are mostly found in tropical countries, and, like the A-c.] Winkles, are very strongly made, to resist the force of the breaking waves. The Neritinas are partly found in the sea, and partly in fresh water, and are less solid shells. The third section of Neritide, the Naricellas, are shaped very much like Limpets, cxcept that the apex is at one end instead of central. They are, however, very different animals, and furnished with a sīnelly operculum imbedded in the foot.

[Case: The Turbinidce and Troclide are two extensive families, the 10n-118.] animals of which are very much alike, and mainly distinguished by the operculum, which in the former is shclly, and horay in the latter. The shells of these families are beautifully pearly within, and the external shelly coat is generally brightly coloured and highly ornamented. Several very pretty species are found on our 
own shores. The opercula of Turbo petholatus (fig. 11), from the Indian and Pacific Oceans, are frequently mounted in gold and silver as scarf-pins, ear-lings, Se.

\section{Fii.: 11.}
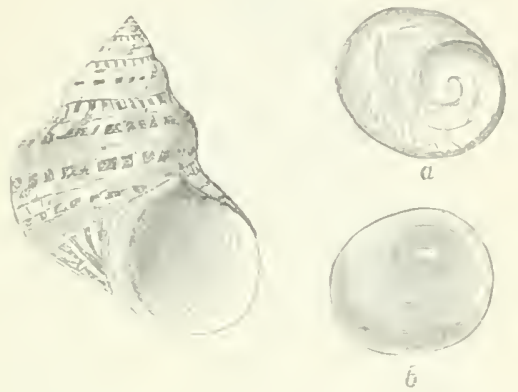

Top-rhell (Twbo petholutus). (From the Indo-Pacific Ocean.)

a. Inner surface of operculum. b. Exterior of ditto.

The "Ear-shells" or " Ormers" (Hatiotide) are found adhering to rocks in most parts of the world with the exception of South Case 11, America. They are lined with pearl, and many exhibit splendid colours and sculpture externally. Like the Limpets they hold on to the rocks with such tenacity that it is absolutely impossible to remore some of the larger species by force without injuring the shell. Boiling water or mustard and water poured orer them will, howerer, soon compel them to relinquish their hold. The shell of Haliotis is pierced by a series of holes parallel with the left margin. Through such of them as are open the animal protrudes a siender. filament or feeler, and the water also finds its way throngh them to the gills bencath.

The single British species (H. tuberculata) is not actually found on the English coast, but common on rocks and stones at lowwater in the Channel Islands. It is frequently eaten by the poor of those islands and the north of France; other species in New Zealand, China, Japan, West Africa, and elsewhere, constitute a common article of dict among the natives. Haliotis-shells are largely used in the manufacture of pearl ormaments, and in all kinds of inlaid work.

The "Keyhole Limpets" and "Slit Limpets" (Fissurellidce) "ase 11. 
Fig. 12.

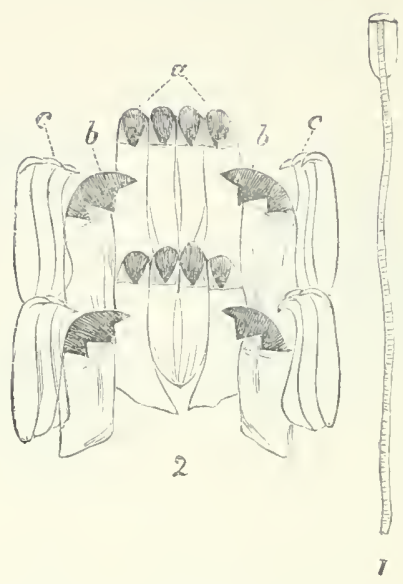

1. Radula of the Common Britisl Rock-Limpet (Patella vulyata), natural size.

2. Two transserse series of teeth: $a$, median teeth; $b$, laterals; $c$, uncini or marginals.

Fig. 13.
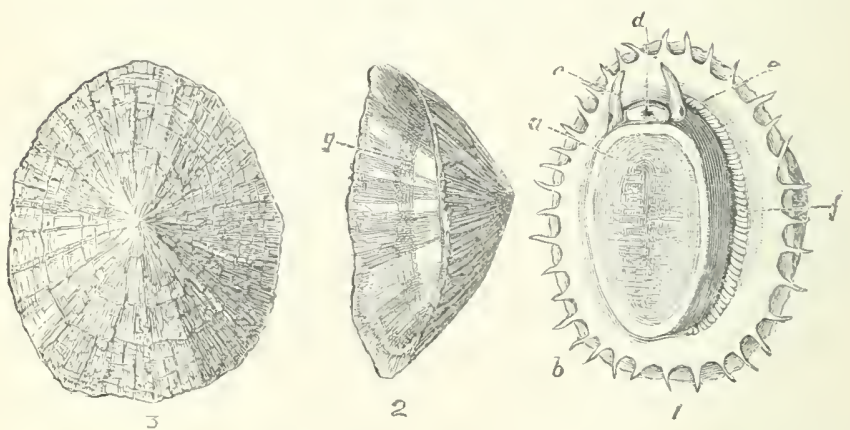

The Common Rock-Limpet (Patella vulgata). British.

1. Animal : $a$, foot; $b$, fringed mantle; $c$, tentacles ; $r$, mouth; $e$, eyes ; f, gill.

2. Side riew of shell, slowing the impression or scar of the attachmentmuscle.

Upper surface of the shell. 
resemble in external shape orelinary limpets, hut are perforated at or near the apex, or more or less slit at the front margin. The hole or slit gives passage to a tubular fold of the mantle, through which the water apparently flows to the rills. 'The largest species are from California and Sonth Imerica, and others are fomnd, but not abundantly, on most shcres. The animal of the large Lucupina cremulata from California is eight or ten inches in length, and almost conceals the shell, and the shell of the South-African Pupillee apertu is also all but hidden beneath the mantle of the animal.

The Acmeide are called false Limpets, becausc, although the shells are identical with the true Imimpets, the animals differ by having only a small gill on the left side of the neck, whilst the Patelice have the gills greatly developed all round the sides of the foot. Both the true and the false Limpets are littoral and found on rocks between tide-nuarks. They lave the power of excavating the surface to which they attach themselves, and aclhere so firmly that it is easier to break the shell than detach the animal. The largest-known Limpet (Patella mexicana) inhabits the west coast of Central America, its shell haring sometimes a diameter of 12 inches. The Limpets are vegetable-feeders and fond of scawceds of various kinds, which they rasp with their remarkable spiny tongues. That of the common English Limpet (P.vulyatu, fig. 1?) is longer than the shell itself, and armed with as many as 1920 glassy hooks in 160 rows of twelve teeth each. The Limpet is commonly used for bait in the sea-fishing off the Scottish coast, and vast quantities are consumed as food in some parts of Ireland. Some Limpets, such as $P$. compressa, $P$. mytilina, \&e., are found on the stems of floating seawecds, and have the shells usually thinner and smoother than the Rock-Limpets, which have to resist the fury of the breaking waves.

The "Coat-of-mail shells," or "Sca-moodlice" (Chitonide), have their back armed with eight shelly plates which overlap one another like tiles, and, like woodlice, have the power of rolling themselves into a ball. Thesc plates are imbedcled at the sides into the fleshy mantle, beneath which, on cach side of the foot, arc arranged the gills. A Chiton differ's in many respects from other Mollusca. It has a shell like an Isopod Crustacean, a heart down

('ase 12, $\mathrm{B}-\mathrm{D}, \mathrm{?}$ 
the back like a sea-worm, synmetrical organs of reproduction on each side like the bivalves, a head and crawling-foot like a true Limpet, and a posterior anal orifice like the Keybole Limpets.

Fị. 11.

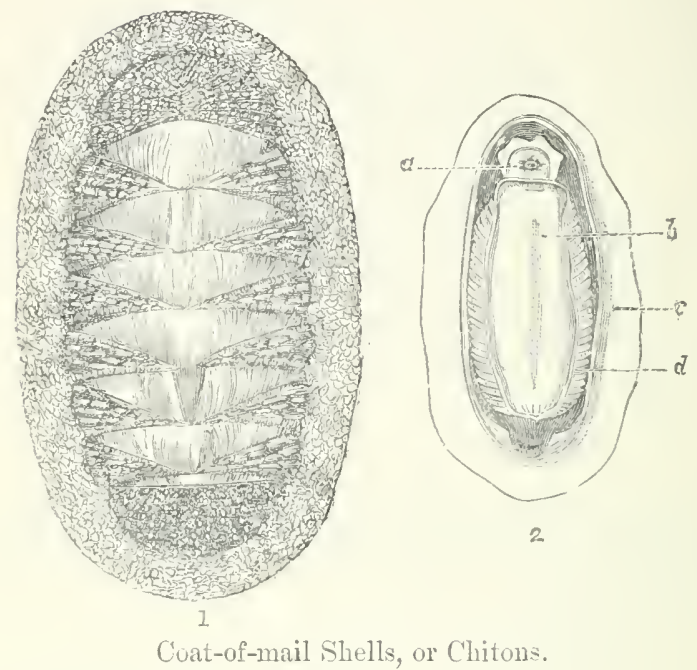

1. Chiton squamosus (upper surface).

2. Chiton clegans (lower surface) : $a$, mouth; $b$, foot; $c$, mantle; $d$, gills.

These sereral amatomical pecnliarities at one time induced certain eminent authorities to hesitate in considering them mollusks; but now that the derclopment from the egg has been investigated, their association with the Mollusea may be eonsidered definitely settled.

Chitons are found in all parts of the world, the finest inbabiting tropical countries. They live chiefly on rocks and under stones at low-water or at moderate depths; but a few forms have been diseovered by the 'Challenger' Expedition at depths exceeding 2000 fathoms. The numerous sections of the group are principally distinguished by differences in the edges of the plates or valves which are inserted in the mantle, and in the different kinds of ornamentation upon the upper surface of the mantle-border. This, in some species, is quite smooth, in others covered with a dense mass of minute grains or scales, and in others armed with short prickly spincs. In the 
griant Cryptocliton of Kamtschatka the plates are entirely covered over by the thick leathery granular mantle, and in another set, Chitonellus, which consists of long slugr-like animals, the plates are very small, and placed at intervals along the back.

Between three and four hundred living species are known, and about one fourth that number has been found fossil from the Silurian age downwards.

\section{OpisthoBRaNCHIATA.}

This section contains a large and varied assembluge of mollusks in which, as already stated (see p. 1.4), the gills are not contained in a cavity over the neck, but placed towards the hinder part of the body, and are either wholly exposed or partly corered by the mantle. This group includes the "Bubble-shells" (Bullide), the "Sea-Hares" (Aplysiidre), the "Umbrellin-shells" (Umbrellide), the Nudibranchs, and some other's.

The Sea-Hares, so called on account of a slight resemblance to a crouching hare and not for their nimbleness of foot, are found

\section{Fig. 15.}

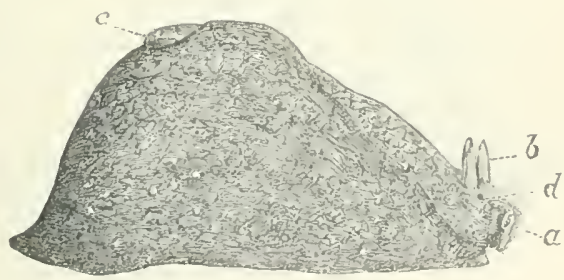

Sea-1 Iare (Aplysue punctutu), British.

$a$, labial tentacles; $b$, uprer tentacles or rhinophores; $c$, siphonal fold of the mantle near the shell; d, eye.

in most parts of the world, in pools at low water. At the hinder part of the back two flaps of the mantle partly conceal a thin horny shell which serves as a protection to the gills and rital organs beneath. When molested, these animals discharge a large quantity of a purple fluid, discolouring the surrounding water for a distance of more than a yard. 
The shell of the Umbrella is shaped very like that useful article of the Chinese pattern. The animal is very large, having its breathing-organs on the right side below the shell.

Fig. 16.

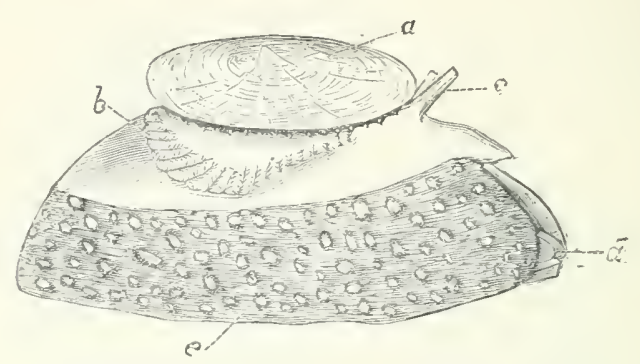

The Umbrella-shell (Umbrella meditcranea).

$a$, shell ; $b$, gills ; $c$, tentacles $d$, , mouth ; e, foot.

Case 12 F.]
The Nudibranchs or Naked-gilled Mollusks comprise some of the most beautiful and strange forms. They are unprorided with shells exeept in the earliest stages of their existence, when they

Fig. 17 .

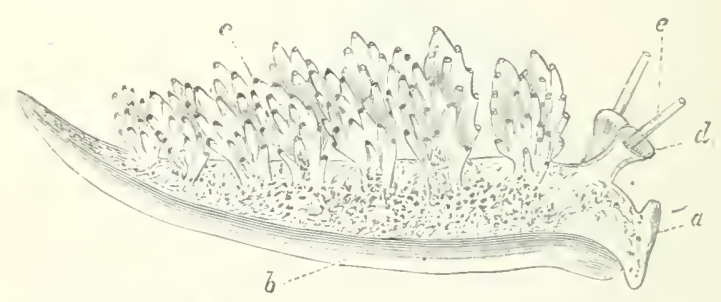

Naked-gilled Mollusk, or Nudibranch (Doto coronata). $a$, head; $b$, foot; $c$, gills; $d$, tentacle-sheath; $e$, tentacle.

dwell in a minute nautiloid shell, furnished with an operculum, both of which are subsequently cast off. Unfortunately the colours of these beautiful creatures cannot be preserved after death, and therefore a small series of glass models is exhibited, which will give some idea of their great variety in form and colouring. They are found in most parts of the world, chiefly in shallow 
water, but a few species live upon floating seaweed in the open sea. Over a hundred species exist on the British coast, the majority of which are, however, very small. They are chicfly earnirorous, fecling on other mollusks, sea-anemones, \&e.

\section{Nucleobraxchita.}

The Heteropods or Nucleobranchs include the Atlantide, Carin- Cisse aria, Sc., and may be considered aberrant Gastropods organized for $\left.1 \cdot 2_{F^{*}}\right]$ swinming in the open sca. The Atlentas are found in great numbers in warm latitudes, and are provided with a glassy, thin, flat, spiral shell, not unlike a keeled ammonite. The glassy shell of the Carinaria is one of the most beautiful structures of any

Fig. 18.

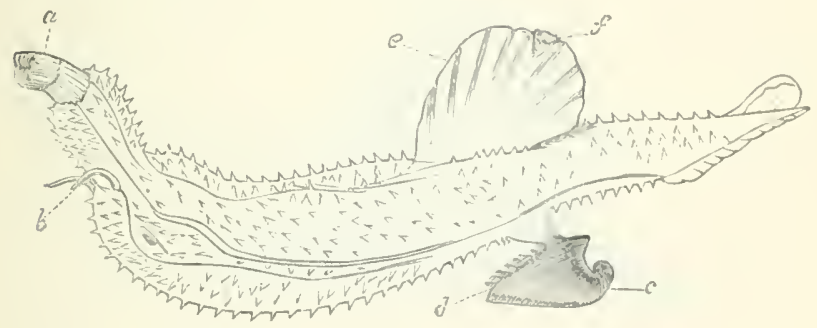

(Hlassy Nantilus (Carizaria lemarckii).

$a$, proboscis; $b$, tentacles; $c$, shell ; $d$, gills; $c$, ioot: $f$, sucler.

mollusk, and at one time was such a larity that $\mathrm{el00}$ are said to have been given for a single specimen, which at the present time is perhaps worth only a few shillings. Species of C'arinariu are found in the Mediterranean and warmel parts of the Atlantic and Indian Occans. The animal is large, semitransparent, and elongate, with a compressed fin-like foot which projects from the body, and is used in swimming. 'The gills are placed towards the hinder part of the back and covered by the shell. They feed on jelly-fish of various kinds, and probably on other soft animals. 


\section{Pulmonata.}

(ases These Cases contain the rast assemblage of true air-breathers. 12G-17n.] Common Land-Snails (Helicide), Slugs (Limacide), certain groups of freshwater Snails (Limnaide), and a few marine Limpet-like Snails (Siphomariide) are the principal types of Pulmonates. About 10,000 speeies are known. True Snails (Helicide) have a distiuct head furnished with eyes, tentacles, cutting upper jaws, and rasping teeth, and all are protected by a spiral shell. They are almost exclusively regetable-feeders, subsisting chiefly on leares. The sexes are not distinct. Species of Helicide are found in nearly every part of the world and in all situations, from sea-level to an altitude of 12,000 feet. They are fond of moisture, and in hot and dry weather retire within their shells, remaining torpid until the

Fig. 1?.

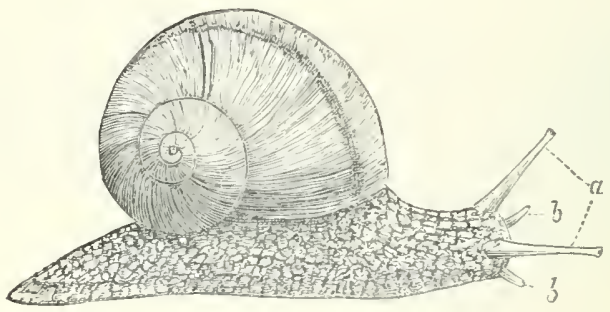

British Land-Snail (IIclix pomatia).

$a$, eve-bearing tentacles ("horns"); $b$, lower or smaller tentacles.

return of dew and rain. Helix pomatia, which is found on the chalk in the south of England and on the Continent, is commonly eaten in Austria, France, and Belgium.

The eggs of Land-Snails vary in texture, size, and in numbers; they are usually white, but in some instances yellow and pale green. Those of some of the large South-American forms are as hard as that of a hen, and more than an inch in length.

Slugs are very like Snails without external shells; most of them, howerer, possess a small internal shelly plate, or a few calcareous granules hidden beneath the skin of the back. Some have a large slime-pore at the end of the foot, and others are slightly phos- 
phorescent. Like the Snails, they are fond of damp localities, and at times become great pests to farmers in derouring the young shoots of the growing corn. Teslucella, which is fouml in this country, differs from the Slugs in having an external shell at the tail-end of the foot. It is not slimy, and lives under ground, fecling upon earthworms.

The first group of the aquatic air-breathers, the Auriculide, case chicfly inhabit salt or brackish water. The largest forms are $17 \mathrm{A.j}$ tropical and found at the mouths of rivers, among the roots and stems of mangrove-trees, or in damp woods ncar the sea.

The Limnceide are only found in fresh water. Most of them occasionally rise to the surface to breathe, where they glicle along Cinse foot uppermost, at times suspending themselves by al shlutinous thread, after the fashion of a spicler. All comntries appear to have their peculiar species.

Fig. 20.
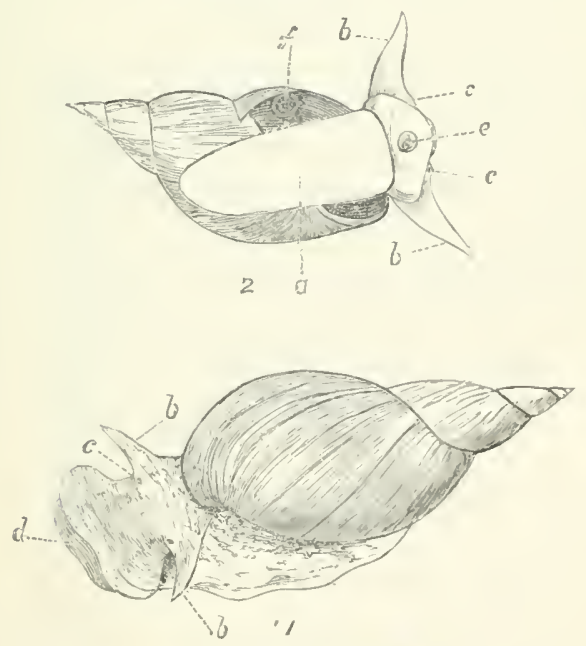

British Pond-Snail (Limnea starnalis).

1. Tpper view : $a$, foot; $b$, tentacles ; $c$, eye; $d$, muzzle.

2. Lorrer view : letters $a, b, c$ as abore; $e$, mouth; $f$, respiratory orifice.

The freshwater Limpets (Ancylus) live attached to stones and Cuso leaves of plants, and have not the labit of floating, but, like the $17 \mathrm{D}$. ] 
rest of the Limncida, feed on freshwater algæ, conferræ, and decayed vegetable matter.

The "Limpet-Snails" (Siphonariide) seem at first sight to be out of place among the Snails and Slugs, and more nearly allied to the Rock-Limpets; but the character of the tongue (odontophore) and the elosed respiratory eavity indicate a close relationship with the present group.

The shells of Siphonaria may be known from Limpets by a slight bulging on one side, caused by a radiating groove which interrupts the muscle of attachment. They are marine, and are found on rocks between tide-marks, chiefly in tropical countries.

\section{SCAPHOPODA*}

The "Tooth-shells" (Dentaliide) form a distinct group, the $17 \mathrm{D.}$ shells of which are very mulike those of any other mollusk, but closely resembling the shelly tubes constructed by certain kinds of marine worms. The Dentalia have neither eyes nor tentacles, or a distinet head like Gastropods; their organs of eirculation and respiration are of a rudimentary kind, and they have no heart. Their foot is adapted for burrowing in sand, in whieh they live and obtain their food, which consists of Foraminifera and minute Bivalves. One species, Dentatium pretiosum, found on the shores of North-west America, was until recently used as money by the Indians.

* From the Greek: scaphe, a small boat, and pous a foot-the foot of some Scaphopods being somewhat pointed like the prow of a vessel.

Fig. 21.
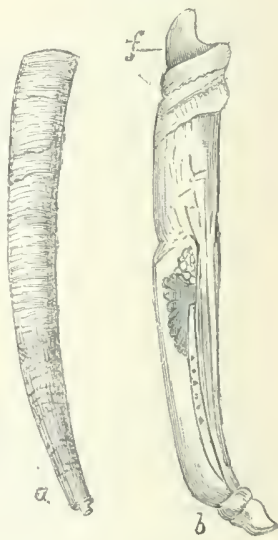

British Tooth-shell (Dentalium tarentinum).

a. The shell. $b$. The animal, removed from its shell $f$, the foot. 


\section{PELECYPOD $A *$, or BIVAINES.}

The Mollusks belonging to this Class have neither head, nor true eyes, nor jaws or tongue like those of the other Classes, and are enclosed in a shell which consists of two plates or valves held together on one side or the margin by a horny, clastic substance, called the "ligement." Bivalves do not ereep abont in search of food, but find their means of existence in the shape of minute particles, both anima! and regetable, which happen to be contained in the water which they breathe. Some, however, are capable of locomotion by means of a well-developed foot, and a few swim through the water by alteriately opening and shutting their valses. The body is enclosed within two lobes of the mantle, which line the interior of the valves, and whicls at their base are firmly attached to the shell, producing on the shell a sear or impression called the "pallial line." The gills are lamellar or leaf-lıke, and placed on each side of the body. The mouth is merely an oval aperture at the anterior end of the body, and generally furnished on each side with soft thin Haps, or labial palps, which have the function of conveying the food to the mouth. The mantle secretes the substance out of which the shell is formed. The two valves are always in contact at the hinge, which is gencrally formed by small interlocking projections or hinge-teeth; and closed by large adductoi muscles, which are attached to impressions in the interior of the shell. When these nuscles cease to act, as after death, the valves of the shell open in consequence of the clasticity of the ligament on the dorsal margin. The majority of species hare two prineipal adductors, one at cach end, like the Venus-shells, Cockles, Razorshells, \&c.; but in Oysters, Scallops, and a few others there is but a single central muscle. All Bivalves are aquatic, and the majority marine. They are found burrowing in sand or attached to rocks. Some perforate stones and corals, others wood, and a few construct a sort of nest of fragments of shells, stoncs, \&.c.

Bivalves may be divided into two sections, the Siphonida and

* From the Greek: pelckus, signifying a hatchet, and pons a foot; the foot of some Bivalies somewhat resembling a hatchet in form. 
the Asiphonida. The former (Cases $17 \mathrm{E}$ to $21 \mathrm{~B}$ ) include such species as liave the mantle prolonged posteriorly into tubular siphons for the admission of water to the gills; and the edges of their mantle are more or less united.

The Asiplonida (Cases $2 \mathrm{l} \mathrm{c}$ to $25 \mathrm{~A}$ ) are destitute of siphons, and have the mantle-margins free. These two main divisions have been subdivided into minor sections characterized by differences in the foot and gills, by the presence or absence of a sinus in the pallial line, the number and position of the hinge-teeth, and the character of the ligament.

\section{SiPHONIDA.}

Cases 17E 18C.

The first family, T'eneride, have long respiratory siphons and a sinuated pallial line. Many of this tribe are very beautiful in form and colouring, and most of them have very hard strong shells. The valves are united above by an external ligament, and the hingeplate is toothed. Nearly all of them live buried an inch or two beneath the sand or mud, but a few are found burrowing in rocks. Probably the majority of the species of this family might be used as food. T'enus verrucosa, of onr omm southern shores, is frequently eaten both in this country and abroad; and Tenus mercenaria is commonly sold in the markets of Philadelphia and New York. Cytherea lusoria also forms a farourite article of diet among the poorer elasses in Japan, and several hinds are eaten by the natives of New Zealand and other comntries.

C'ase

Is $\mathrm{D}$.

C'ases $18 \mathrm{E}-19 \mathrm{P}$.

Of the Corliculide, the genera Cyrena, Batissa, and Velorita are found in brackish water at the months of rivers or in Mangrove swainps, and the smaller forms, as Corbicula, Splcerium, and Pisidium, live in fresh water.

The Tellinas have usually thinner shells, and their two siphons are longer and more completely separated from each other than in the Venerids. The pallial line is widely and deeply sinuated, and the ligament generally external, except in the genus Semele, where it is placed within the linge-margin. They live in great numbers beneath the sand in shallow water, and are occasionally used as food.

Case 19, The Mactride have an internal ligament to the hinge, the siphons 
"lie joined together and fringed at the ends, and the pallial line is mure or less sinuated. Mactra sulidissima, the largest species fuund on the coast of the United States, is a common article of diet.

The genus Chama consists of tropical species, which are found fixed to corals, rocks, sce. Nerertleless, they hare a small bent foot, but what purpose it serres is difficult to conceive.

Some of the "Cockles" (Cardiidce) from warm latitudes are highly coloured and adorned with most beautiful sculpture. Probably the majority are eatable, as the common coekle (Cardium edule) of the British coast. The foot of these mollusks is rery large, bent, and used for leaping. The siphons are short and fringed at the margins.

The Tridacnida, or true Clams, differ from other Bivalves with united mantle-margins in having but a cenFig. 르.

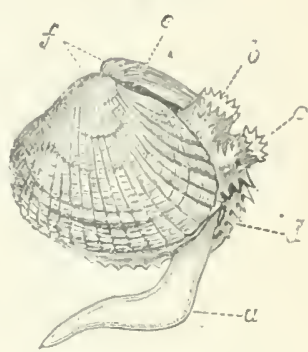

Common British Cockle

('urdium edule).
[Case 19, E. F. ]

Casez

$19 \mathrm{G}-20 \mathrm{~s}$. trial adductor muscle. In the typieal species the animal is attached to the rocks by a "byssus," a strong fibrous structure which passes

Fị. :2:?.

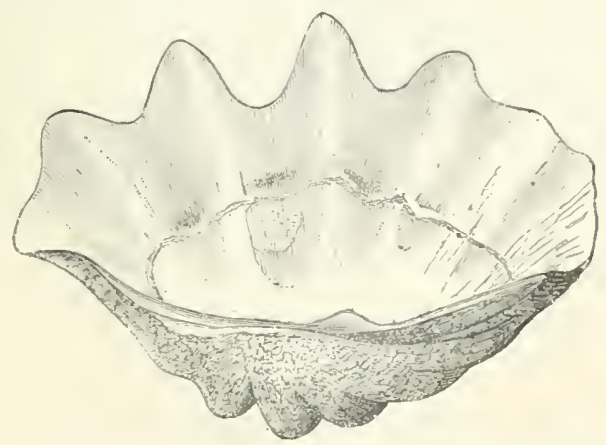

Left valre of the Giant Clam (Tridacna gigas).

Length, 36 inches. Weight, $154 \mathrm{lb}$; weight of the two valres, $310 \mathrm{lb}$. 
through an aperture at the upper part of the shell. A species found in the Red Sea, T. elongata, is caten by the natires, and the shell employed for the mannfacture of lime. Tridacna gigas, the largest known bivalved mollusk, sometimes weighs over $500 \mathrm{lb}$., that exhibited on the floor of the Gallery being $310 \mathrm{lb}$. in weight. A large pair bordered with gilt copper are used as bénitiers or holywater vessels in the church of St. Sulpice in Paris. Tridacne are found associated in large numbers in lagoons, among coral-reefs in the Eastern and Pacific Seas. The animals are described as presenting a beautiful iridescent glare of blue, violet, and yellow, variegated with fantastic markings,

[Case 20

The Pholadide, or Piddocks, are very remarkable shells, of an B-D.] unusually complicated structure, some having the power of boring into rocks, wood, mud, sand, Sc. Their shells are white, adorned with prickly sculpture, and, although thin, are strong. The foot is believed to be the principal exearating instrument, but the shell no doubt is nsed as a file to enlarge the hole as the creature grows. These animals are brightly phosphorescent; and certain species are eaten at many places on the shores of the Mediterranean. They appear to be indifferent as regards the

Fig. 21.

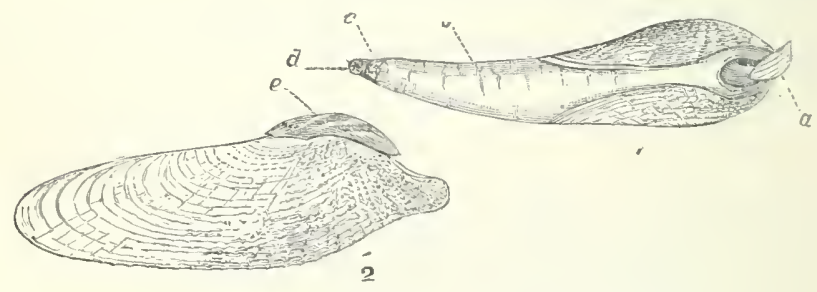

Piddock, or Borer (Pholets dectylus). (From the British const.)

1. Animal in the shell $: a$, foot; $b$, siphons ; $c$, inhalant orifice: $d$, exhalant orifice.

2. Shell: e, accessory ralres or plates.

material they bore into; for the common Pho'as dactylus (fig. 2. of our own shores has been found in slate-rocks, mica-schist, coalshale, new red sandstone, chalk, marl, peat, and submarine wool. 
The siphons are long in the Piddocks, united execpt ncar the end, and enclosed in tough skin. The speeies are world-wide in their distribution, and several are found fossil in some of the Tertiary formations.

The Teredinide, or Ship-rorms, are also borers, like the Pholads, but do not perforate rocks. They are principally wood-borers; the large $K u-$ phus arenaria, which is an exception, living buried in the sand. The Shipworm has a long worm-like body, from 6 to 12 inches in length, which is more or less enclosed in a thin shelly tube or sheath. The true bivalved shell is at the thicker end, and protects the mouth, labial palps, the liver, and other internal organs. At the opposite, or more slender, end of the animal, the mantle is produced into two small tubes, one of which conveys the water to the gills, whilst through the other the water is expelled, charged with the woody pulp excarated by the foot. At the end there is a pair of pallets, or paddles as they are sometimes termed, which are probably used as a means of defence, in closing the shelly tube after the contraction of the siphons.

These animals are most destructive to ships, piers, scc; and wood, which is not protected by metal, when once attacked, is soon riddled through and through. They generally work with the grain, and only turn aside when a knot comes in their way; and although the holes may be all but touching, they seldom appear to run into one another.

The "Watering-pot shell" (Brechites) is a very remarkable strueture, and unlike the shell of an ordinary bivalred mollusk. On looking carefully, however, near the perforated end (the 
rose), two snall valves will be seen imbedded in the surface. They are found with the rose clownwards buried in mud or sand at low water on the shores of the Indian and Pacifie Oceans.

Fig. 26.

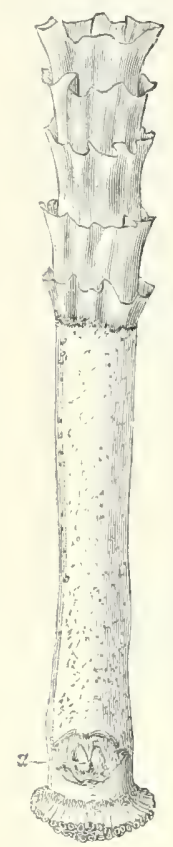

Fig. 2-7.

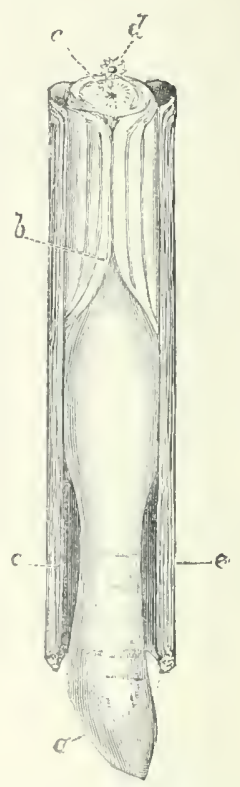

Fir. 20. Watering-pot Shell (Breehites vayiniferum) : a, biral se shell of the very young animal.

Fig. 27. British Razor-shell (Solen siliqua) : $a$, foot: $b$, mantle; $c$, inhalant siphon; $d$, exhalant siphon ; $e$, shell.

[Case 20, I-F.]

Many of the Solenidce, or Razor-shells, possess rery elongated shells, and are remarkable for the great development of the foot, which ean be pointed or eontracted as may be required for boring into sand. By means of this powerful foot the animals, when disturbed, bore with such rapidity and to sueh a depth that their eapture is a matter of great diffienlty; and even when seized they hold on so tightly that at times they suffer their foot to be torn off rather than be captured. They not only burrow in sand, but also have the power of darting throngh tle water, like the Scallons. 
Solens were considered a dainty dish by the ancient Gireeks, and numbers are still eaten by the poorer coast-population of this country and abroad.

The Myide, popularly known as "Gapers," on account of their (ace. valves being open at one or both ends, have the mantle united all - in. round, exeept where the small foot is protruded. The siphons are

Fï. 28.

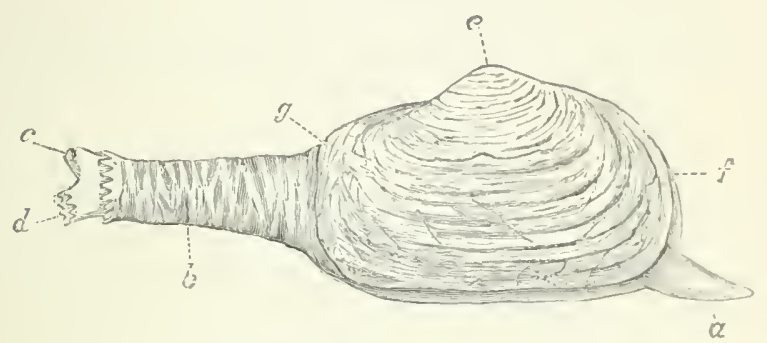

British Gaper' (MYya truncuta).

$a$, foot ; b, siphon-sheath ; $c$, exhalant siphon; $d$, inhalant siphon : $e$, umbones or beaks; $f$, anterior, y, posterior end of shell.

very long, united almost to the ends, and covered with a eoarse wrinkled outer skin. They bury themselves in mud and sand at low-water mark or in shallow water. The species are fer in number, and chiefly from the shores of northern countrics. I/ya arenaria of our own coasts is largely eaten in some parts of Europe and North America.

The family Corbulide contains a large number of mostly small shells, varying much in shape and seulpture. Tlhe true Corbule Case 20 (i. have one valve larger than the other and are like little Myce, but the valves are almost closed and their siphons are very short.

The Lucinida are almost invariably white shells, and may generally be recognized by the rery long muscular sear in front on the inner surface of the valves. They occur in all parts of the world; and the fossil forms, which are still more numerons than those now living, have existed at every epoel from the Silurian.

The Astartide have strong solid shells, frequently ornamented 
with radiating or concentrie ribbing, and usually are coated with a dark epidermis. They have the general appearance of certain Veneride; but the animal has no prolonged siphons, but merely a fringed opening in the mantle. One very remarkable species, Thecalia concamerata, has an internal cup-like process within the valves, which serves as a nursing-pouch for the young.

\section{AsIPHoNida.}

C'ases

Of the freshwater IIussels or Unionide more than 1200 species 21C-2. $\mathrm{H}$. world, the greatest number having been described from North America. In Lnio the edges of the mantle are not united along the bottom and not prolonged into siphonal tubes; at the posterior end there are two openings, of which the npper or excretal orifice is simple, and the lower or branchial fringed at the edge. The foot is very large and adapted for crawling and burrowing. The sexes are distinct; and the shells of the females are somerrbat more tumid than those of the males. Hargaritana margaritifera, which is found in this country and in Europe, sometimes produces handsome pearls, but not equal to those obtained from the pearl-oyster of tropical seas.

rCase

23. A.]

The family Atheriida, or freshwater Orsters, consists of but three genera: AEtheria contains African, and Mülleria and Bartlettia South-American forms. When young the shells of Etheria (which are common in the Nile) are free and not unlike an Anodonta, but when adult they become attached and irregular and look like an olire-green Oyster; they are, however, prorided with two muscular impressions instead of one, as in ordinary marine Oysters. Still more remarkable is Mülleria of Ner Granada, which, when young, freely moves about and has two addnetor muscles, but in time becomes attached and stationary, and then possesses but a single adductor.

Case 2:3. A-E.]

The Alytilida, or M[ussels, are too well known to need description. The small foot, which is brown in the comnon species, is not much used in creeping abont, but has the power of spinning a byssus or bundle of tongh threads, by means of which the animals attach themselies to rocks and one another, forming colonies of vast number's. Mussels have always been much eatcu in this and other 
maritime countries, and large quantities are brought to the London market from the Dutch coast. At times they are unwholesome; but all the exact causes of this are not known. Musscls seem to be found on every shore, and some of the speeies are very widely distributed-the conmon edible Mussel, $M$. edulis, being found on every European coast, on the shores of North and South Ameriea, in the Aretic and Antaretic Oceans, and probably on the coasts of Anstralia.

One group of Mussels (Lithodomus) burrow in rocks and other shells, forming holes just large enough to eontain their shells. L. dactylus is sold as an article of diet on the shores of the Mediterranean.

The Trigoniide are one of those families which have all but disappeared during our period. Only three or four living specics are known, whilst more than a hundred fossil forms have been deseribed from the Jurassic and Cretaccous formations. Australia, where some of the oldest types of animal life persist, furnishes also the existing species of Trigonia. The animals have a long, sharply-bent, pointed foot, like the Cockles, with which they make surprising leaps. The shells are beautifully pearly within, and ribbed and noduled exteriorly.

The Arcide are a family of strong ponderous shells varying much in form and sculpture. The animals have a longish pointed foot, deeply grooved along the bottom, no labial palpi, and free margins to the mantle, which are not prolonged into breathingsiphons. Many of the Arks often anchor themselves by means of a strong byssus. The shells of this family are usually radiately ridged; and the hinge is composed of a number of tceth arranged along the hinge-line, which is generally straight. Arca tortuosa, from China, has the valves curiously twisted. The section Barbatia is remarkable for the coarse fibrous character of the epidermis; Scapharca for its unequal valies; and Cuculloa, from the Indian Ocean, for the elevated ridge bounding the posterior muscular impression. Pectunculus lias the hinge-teeth arranged in an arched series, and the shells are more regular in growth than in many other forms of Arcida.

The next large family, the Aviculide, includes Pinna, the [Case 24, "Wing-shells" (Avicula), the "Pearl" and "Hammer Oysters" A ir.] 
Fix. 29).

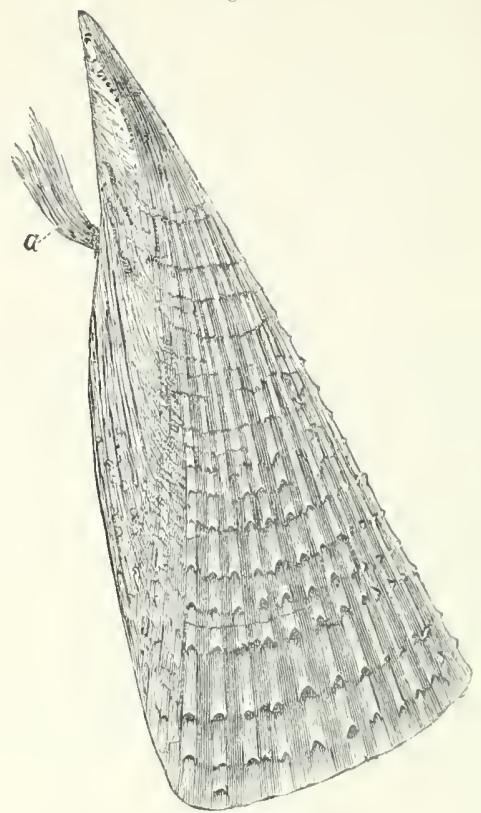

British "Fan-Mussel" (Pinna pectmata): a, the by s:us.

Fig. 20 .

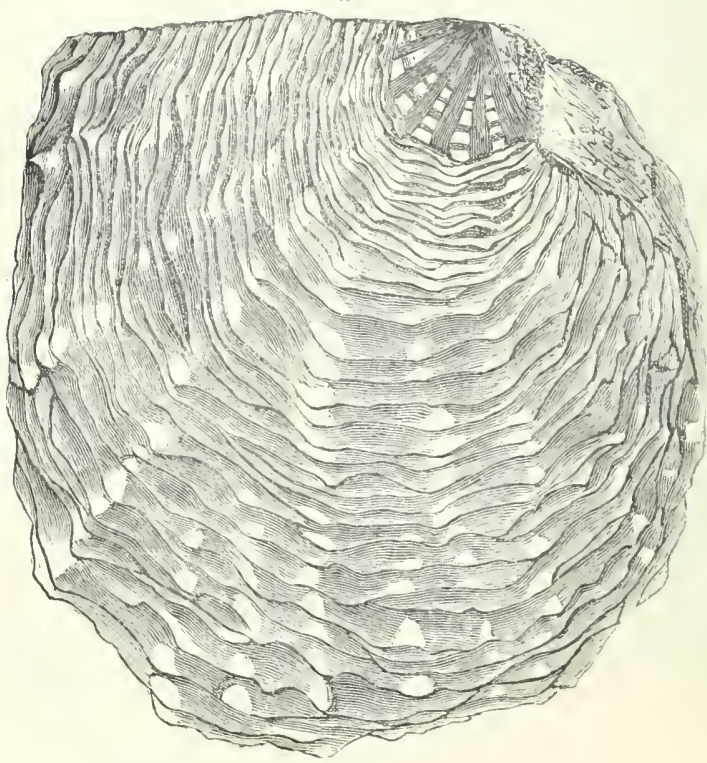

Pearloyster' Meleagrina margantifera). 
(Meleagrina and Malleus). Some species of P'inna attain to a length of two feet. 'They are found imbedded in the sand with the narrow pointed cod downwards. They form a large silky byssus, which can be woven or knitted into gloves, socks, Se. (sec Table-case II). The "Hammer-Oyster" (Malleus) is so called from its rude resemblanee to a hammer. The "Pearl-Oysters" (Meleagrina margaritifera) possess rather heavy strong shells, lined with very thick layers of "mother-o'-pcarl." IIundreds of tons of these shells are annually collceted at the great pearl-fisheries of Ceylon, the Persian Gulf, and West Australia, and imported into Europe. 'The round pearls, which are valued so highly, are cither exerescences of the pearly laycr or are found loose in the fleshy parts of the animal. Some small foreign body whieh has aecidentally penetrated under the mantle and irritates the animal is covered with successive eoncentric laycrs of naere, thus attaining sometimes, but rarely, the size of a small filbert. The nacre is generally of the well-known pearly-white colour, very rarely dark, and oceasionally almost black. The effort of the animal to get rid of the irritation caused by a foreign substance between its valves, by eovering it over with nacre, and thus converting it into a pearl, is strikingly illustrated by two specimens in which, in the one case, an entire fish, and in the other a small crab, have been so enclosed (see Table-case $\mathbf{F}$ at the end of the Gallery).

One of the most ancient and, at the present day, the most important of the pearl-fisheries is that earried on on the western shores of Ceylon. "The Banks," or spots on which the oysters grow, are at an average depth of 30 to 60 feet, and extend several miles along the coast. The oysters, which should be six or seven years old when collected, are gathered in baskets by native divers and hauled up by ropes into hundreds of small boats. The shells are then brought to land and placed upon the ground to die and putrefy, and then minutely examined for the pearls, which are either found loose in the shells or imbedded in the fleshy parts of the oysters. As many as two million oysters have been brought ashore on one day; but the number obtained varies very much according to the state of the banks. A small proportion of the oysters contain pearls; in some only very small ones (seed- or dustpearls as they are called) are found, and very few contain pearls 
larger than a pea, which are so highly valued. In his account of the pearl-fishery of Ceylon the Rev. James Cordiner says that he saw the operation of sorting the pearls performed; the produce of 17,000 oysters weighed only $\frac{3}{4} \mathrm{lb}$. and was contained in a vessel smaller than a common soup-plate. Out of that quantity there were not found two fine perfect pearls; all of the largest were slightly deformed, rugged and uneven, but of the smaller sizes many were round and perfect. The chief qualities which regulate the value of pearls are size, roundness, and brilliancy of lustre. Of the smallest kind several may be bought for a shilling, whilst many thousand pounds have been given for a single fine pearl of surpassing beauty.

Other important pearl-fisheries besides that of Ceylon are carried on in the Persian Gulf, on the west coast of Central America, and especially North-west Australia, where diving-dresses are now employed in collecting the shells.

The Chinese obtain pearls artificially from a species of freshwater Mussel (Dipsas plicata). In order to do this they keep them in tanks and insert between the shell and the animal either small shot or small round pieces of mother-of-pearl, which soon receive regular coatings of nacre and assume the look of ordinary pearls. They also insert small metal images of Buddha, which also soon become covered with pearl and firmly cemented to the shell, the production being to the uninitiated a supernatural testimony to the truth of Buddhism. (A shell treated in this way is exhibited in one of the small cases near the entrance to the room.)

Cases

$24 \mathrm{II}-$ $25 \mathrm{~B}$.

Case 25 B-F.]
The Spondylida, or Thorny Oysters, closely resemble the Scallops, but the shells"are more spiny, heavier, united by interlocking teeth, and one of the valves is attached to rocks, corals, \&c. Many of the species are very brightly coloured; and from the fact that small quantities of water are sometimes enclosed in cavities in the inner layer of the shell, they have been called "Water-Clams" or "Water Spondyli."

The Scallops or Fan-shells (Pectinide) are wcll known for their beautiful colours, sculpture, and excellent flavour. The animal has a distinct foot, which is not, however, used as a locomotive organ, but employed in spinning a byssus of attachment when required. The young Pectens dart through the water by 
opening and suddenly closing their valves. The species are very numerons, world-wide in their distribution, and may be found at depths from a few to thee thousand fathoms.

The Limas (Limide) are very like the Peetens, but the inner edge of their mantle is fringed with very long thread-like filaments. The I'ise shells are always white, gencrally nore or less oblique, and radiately ridged. They appear to be found in most seas, and either swim about freely like the young Scallops by flapping their valves, or attach themselies by a byssus, sometimes forming a sort of nest, consisting of pices of eoral and shell or small stones, in which they are completely concealed.

The Ostreide, or Oysters, undoubtedly take the first rank [Case 25, $\mathrm{F}-\mathrm{H}$. $]$

Fir. : :1.

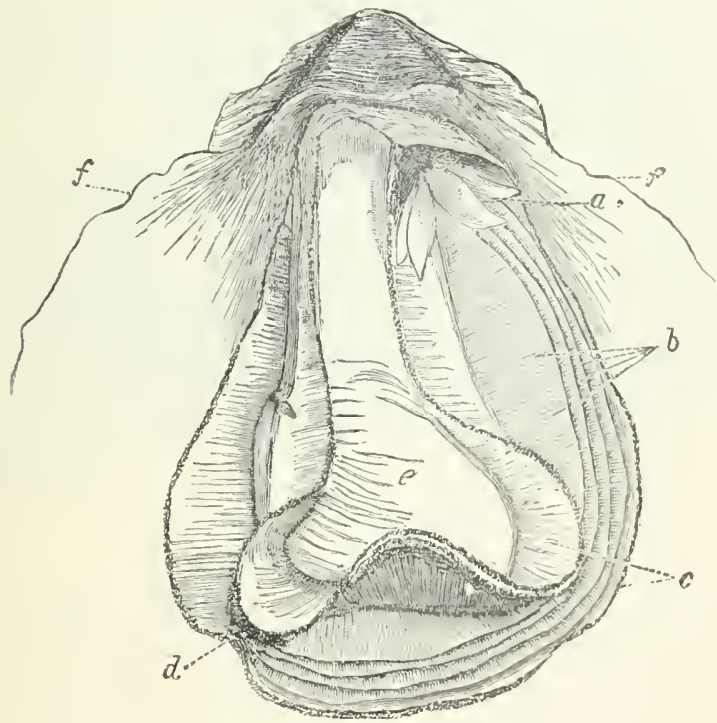

Common Edible Oyster (Ostrea edulis).

$a$, labial palpi ; $b$, gills ; $c$, mantle ; $d$, junction of the two folds of the mantle; $e$, large adductor muscle; $f$, the shell.

among mollusks as regards uscfulness to mankind as an article of food. They have no foot; the mantle is entirely open, with double 
edges, each being bordered by a short fringe, and the labial palps are large and somewhat triangular. There are on each side a pair of simple gills, which are closely striated; the single adductor muscle is large and nearly central. The Oyster is, except in the very young state, entirely incapable of locomotion, and always attached by the deeper valve to other shells, rocks, or other substances. The common British species is not full-grown until it is about five or seven year's old. A series of different ages, from the "spat" to the adult form, is exhibited in Case $25 \mathrm{~F}$. During the months of May, June, and July the eggs are diseharged into the gills, where they remain until hatched; and it is during this period that oysters are "out of season." In the American Oyster (O. virginica), on the contrary, the eggss are said to be hatched outside the parent shell. Oysters of different kinds are found on nearly every shore. The gigantic $O$. gigas is said to grow to the length of three feet in the Bay of Taichou, Japan, where it is commonly caten. About two hundred fossil species have already been described.

Case 26 A. $]$

[Case $[6, A-B$.

Case $26, \mathrm{~B}-\mathrm{G}$.

The family of Anomiide contains a number of more or less pearly shells remarkable for a deep notch or hole in the lower or flat valve through which a shelly plug passes, by meaus of which the animal attaches itself to other shells, stones, Sc. Anomia anigmatica is found adhering to leaves in mangrove-swamps.

The Placunida, sometimes called Window-shells and SaddleOysters, are very tlat pearly shells with a remarkable hinge, which consists of two long divergent teeth, like a $\mathbf{\Lambda}$, to which the ligament is attached. The species are few in number, and inhabit sandy shores of India, China, and North Australia.

In sections B-D of Case 26 is exhibited a number of shells which, either from the attacks of worms or from reparation of injuries, or from other causes are very much distorted in growth or monstrous. In division $\mathrm{E}$ some sections of shells are exhibited showing their internal structure. In the same and following division (F) are some specimens of rocks, corals, and wood, illustrative of the perforating power's of the boring linds of Mollusca ; and in division $G$ is exhibited a series of shells of pearl-forming mollusks. 


\section{BRACHIOPODA.}

These animals, which for a long time were elassed with the Mollusea, are now eonsidered by some naturalists, ehiefly upon [Case ¿6 II.] embryologieal grounds, to be more nearly related to Annelids or marine worms. Others maintain that their aftinities lie rather with the Polyzoa and Tunieata, with which they form a distinct class, termed Molluscoida. The Brachiopoda offer considerable

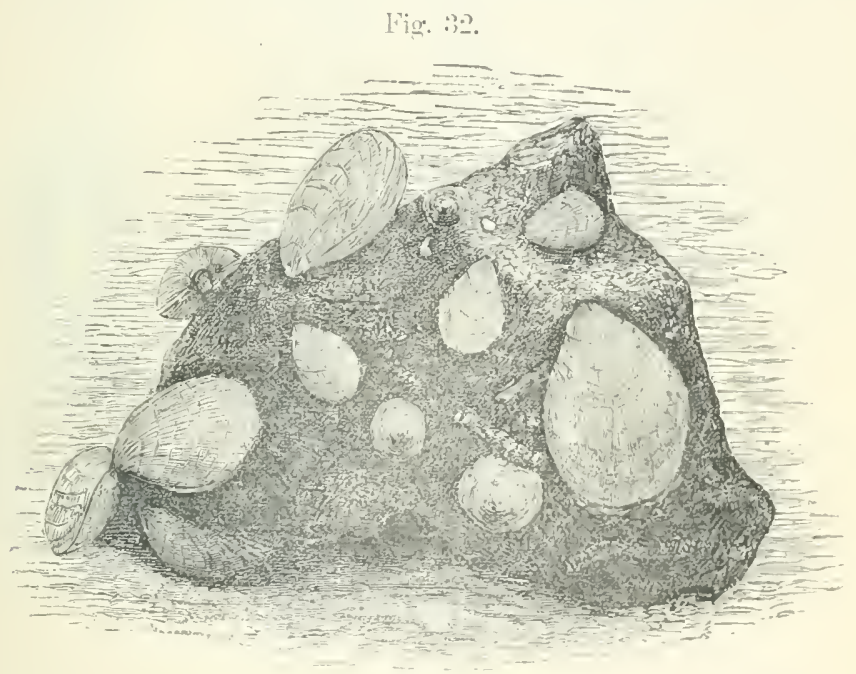

British Brachiopods (Terebratuli and Cramia).

external resemblance to bivalve Mollusea, from which, however, they differ in being always equilateral, never quite equivalse, and in having neither a foot nor gills, respiration being performed by the lobes of the mantle and two ciliated arms near the mouth. These are generally supported by a shelly appendage, by the form and disposition of which the various genera are distinguished. Brachiopods are marine, and always attached either by the surface of one of the valves or by a peduncle which passes through a hole at the beaked end of the shell, as in the Lamp-shells (Terebratula). The valves are unconnected by a ligament and not 
placed on each side of the animal, as in the bivalve mollusks, but are respectively dorsal or ventral or upper and lower. In Terebratula, Rhynchonella, \&c. they are locked together by a kind of hinge, which is so constructed that it is almost impossible to separate them without injury. Crania, Lingula, and others have no hinge, the valves being merely held together by muscles. Brachiopods are found in all seas, attached to rocks, corals, and other bodies. They are found at any depth, in pools at low-water mark or in 2900 fathoms. Only about one hundred and forty species of living Brachiopods are now known; but at former periods they were much more numerous, over 1800 extinct forms having beeu described.

Duck's-bill Lingula (Lingulu anatinu). (From the Indian

Ocean.) 


\section{ALPПАВETICAL INDEX}

OF TIIE

\section{FAIILIES AND PRINCIPAL GENERA OF MOLLCSCA EXIIIBITED IN TIIE SIIELL G.LLERY.}

This Index has been eompiled to assist the mumerous visitors, who wish to examine and detcrmiue specimess of shells, in finding, without trouble or los: of time, the Case in which the genera are placed. Subgeneric telms are omitted, as they do not fall within the scope of this "Gride."

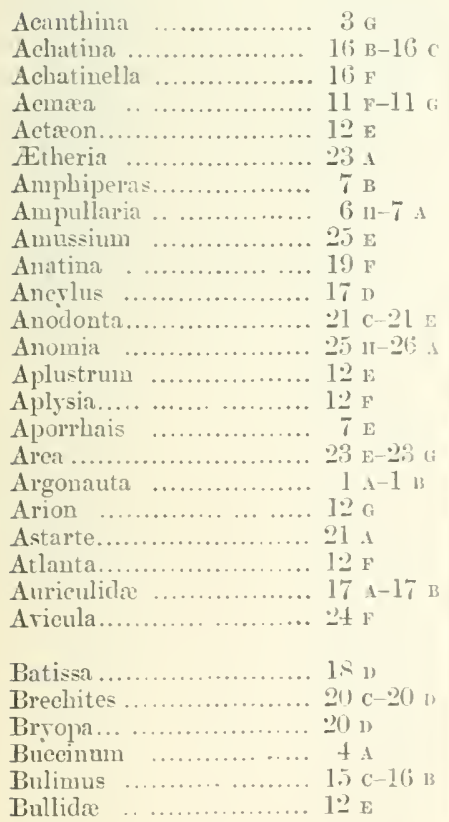

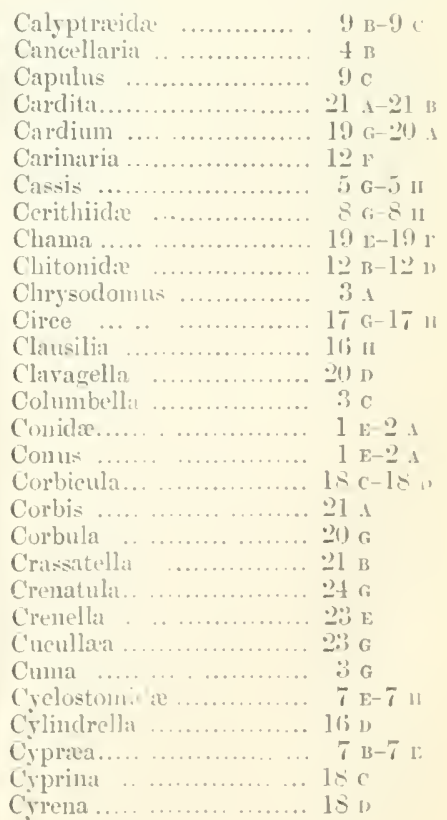




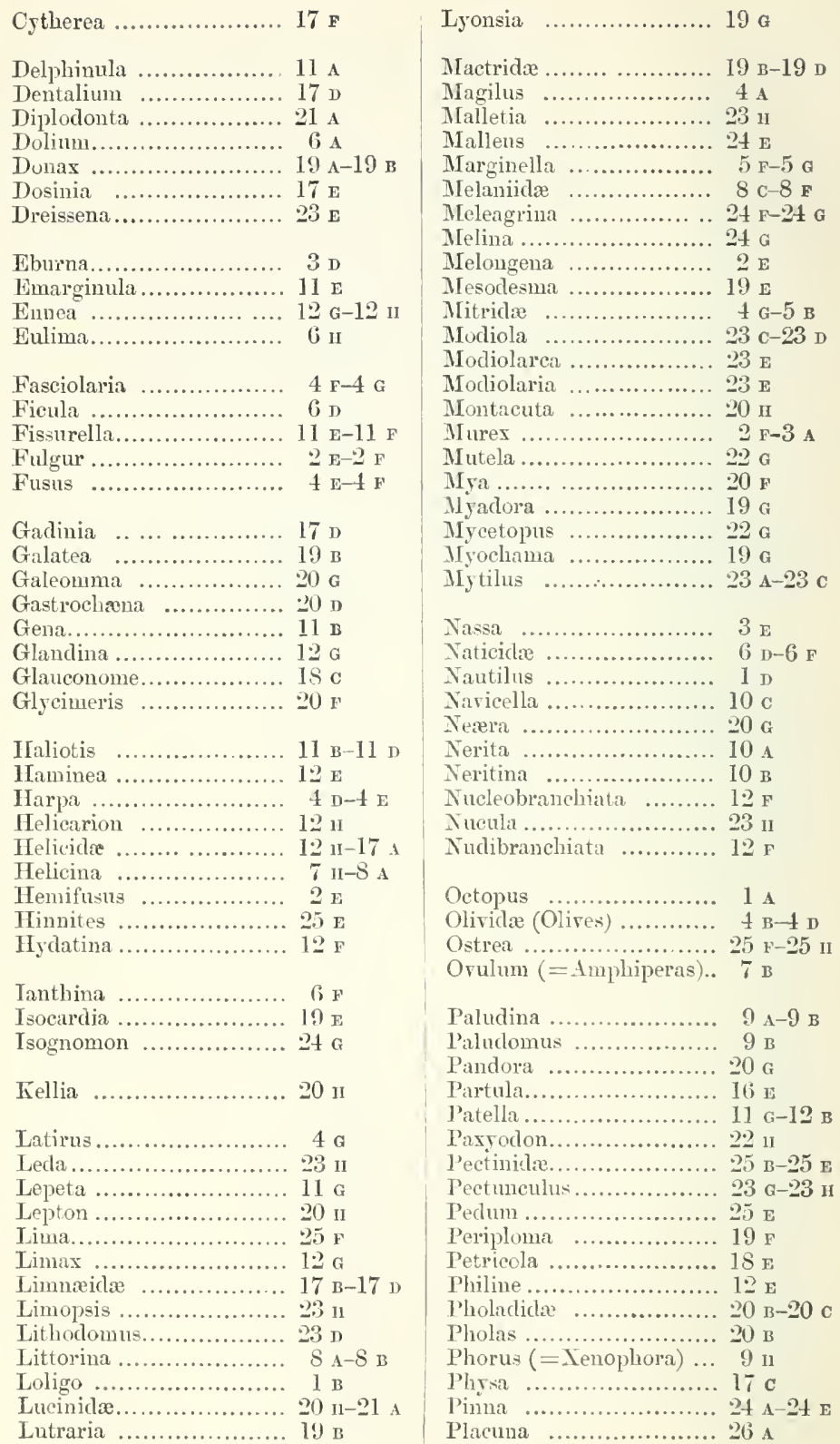


Planaxis ................. $8 \mathrm{c}$

Planorbis ...................... $17 \mathrm{c}$

Pleurotomida ............. 2 $\mathrm{c}-2 \mathrm{E}$

Plicatula ................... 25

Proserpina .................. $10 \mathrm{c}$

Pterocera.................. $9_{\mathrm{a}}$

Pteropoda ............... I D

Puncturella ................ 11 k:

Pupa....................... $16 \mathrm{~g}$

Purpura ................. 3 G-3 н

Pyramidellidax.............. $6 \mathrm{G}$

Ranella................... $6{ }^{A}-6 \mathrm{~B}$

Ringicula................. 6 it

Rissoidre .................... \& $8 \mathrm{c}$

Rocellaria.................. $20 \mathrm{p}$

Rostellaria ................ 9 $\mathrm{nI}$

Rotella..................... $10 \mathrm{c}$

Saxicava .................. $20 \mathrm{p}$

Scalaria .................. (i $\mathrm{F}$

Scaphander ................ I: $\mathrm{E}$

Scintilla ................... $20 \mathrm{G}$

Scutus ................... $11 \mathrm{D}$

Semele ...................... 19 A

Sepia........................ $1 \mathrm{c}$

Septifer $\ldots \ldots \ldots \ldots \ldots \ldots \ldots . . . \ldots 28 \mathrm{E}$

Siliquaria.................. $9 \mathrm{E}$

Siphonaria ................ $17 \mathrm{p}$

Sistrum .................. $t$

Solarium .................... 6 it

Solemya .................. $20 \mathrm{G}$

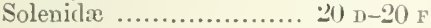

Sphærium ................ $18 \mathrm{E}$

Spirula..................... $1 \mathrm{c}$

Spondylus ................ 24 ЕI-25 в

Stilifer ..................... (i) II

Stomatella .................. 11 B

Streptaxis.. ................ 12

Strombus .................. $99_{\mathrm{E}-9} \mathrm{G}$

Strophia

16 ॥

\begin{tabular}{|c|c|}
\hline 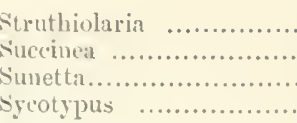 & $\begin{array}{l}75 \mathrm{v} \\
17 \mathrm{~A} \\
2 \mathrm{v} \\
25\end{array}$ \\
\hline 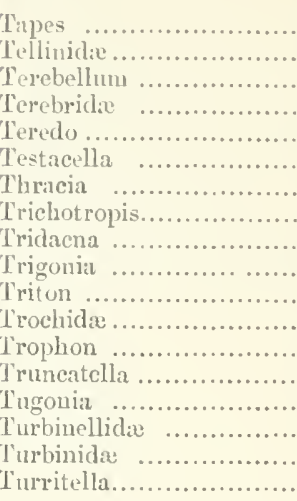 & $\begin{array}{l}18 \mathrm{~B} \\
18 \mathrm{~L}-19 \mathrm{~B} \\
9 \mathrm{H} \\
2 \mathrm{~A}-2 \mathrm{C} \\
20 \mathrm{C} \\
12 \mathrm{C} \\
19 \mathrm{~F} \\
7 \mathrm{E} \\
20 \mathrm{~A}-20 \mathrm{~B} \\
23 \mathrm{E} \\
6 \mathrm{~B}-6 \mathrm{D} \\
10 \mathrm{~F}-11 \mathrm{~B} \\
3 \mathrm{~A} \\
8 \mathrm{~B} \\
20 \mathrm{~F} \\
5 \mathrm{~B}-5 \mathrm{C} \\
10 \mathrm{C}-10 \mathrm{E} \\
8 \mathrm{11}-9 \mathrm{~A}\end{array}$ \\
\hline 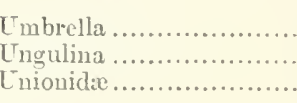 & $\begin{array}{l}12 \mathrm{r} \\
21 \mathrm{~d} \\
21 \mathrm{E}-22\end{array}$ \\
\hline 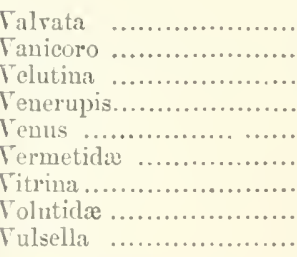 & $\begin{array}{l}9 \mathrm{H} \\
9 \mathrm{I} \\
6 \mathrm{D} \\
18 \mathrm{C} \\
17 \mathrm{H}-18 \mathrm{~s} \\
9 \mathrm{D}-9 \mathrm{E} \\
12 \mathrm{H} \\
5 \mathrm{C}-5 \mathrm{~F} \\
2411\end{array}$ \\
\hline 1. & $9 и$ \\
\hline
\end{tabular}

Struthiolaria ............. $7 \mathrm{r}$

Nuccinear .................. 17 17

Sunettn................... $17 \mathrm{k}$

Times ...................... $18 \mathrm{n}$

Tellinidie .................... If 2:-19 в

Terebellum ................ ! $\mathrm{n}$

Terebridse .......... $10.2 \mathrm{c}$

Teredo ....

Testacella $1: 2$ a

Thracia ................... 19

Irichotropis............... \%

Tridacna ........20 $1-20 \mathrm{~B}$

Trochide.................. 10 r -11 B

Trophon ................... $3 \mathrm{~s}$

Truncatella .................. $\&_{13}$

Tugoulia

Turbinellidac ............. 5 $\mathrm{B}-5 \mathrm{C}$

Turbinida ............... 10 $\mathrm{c}-10 \mathrm{E}$

Umbrella ................. $12 \mathrm{r}$

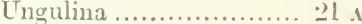

$-1 \mathrm{E}-22 \mathrm{G}$

Talrata

Telutina

Tenerupis................... 18 o

政 18 .

Termetida

Titrina................... 12)

Volutidæ ................. 5 ( -5 F

Tenophora ............... 9

Foldia ..................... 23 n 



\section{ThE STARFish Gallery,}

The Starfisi Galeen contains a selected series of the animals belonging to the class Echinodermata, of which the Starfishes are one of the best-known types, but which, besides, includes the Crinoids, Sea-Urehins, and Sea-Cuemubcrs or Sea-Slugs.

A small collection of various kinds of Trorms is also exhibited in this Gallery (Wall-cases I.-III.).

\section{ECHINODERMATA.}

Table-cases 1-6 contain the dried Echinoderms arranged in systematic order. Table-case $\sigma$ is devoted to preparations, models, and figures illustrative of the structure and life-history of various members of the group.

An inspection of that Case and the accompanying woodcuts will make clear the distinctive characters of the Echinodermata. Unlike that of a Crayfish or a Mussel, the body is not divicled into two equal or symmetrical halves, but is produced into a number of rays, of which there are ordinarily five. The shin is strengthened by the deposition in it of carbonate of lime, which may be in the form of continuous plates or bars, or of separate scattered spicules. A series of tube-feet or suckers are generally developed along each ray, and these are supplied by a system of water-ressels peculiar to Starfishes and their allies. These rays are often called " ambulacra." 
Fig. 34.
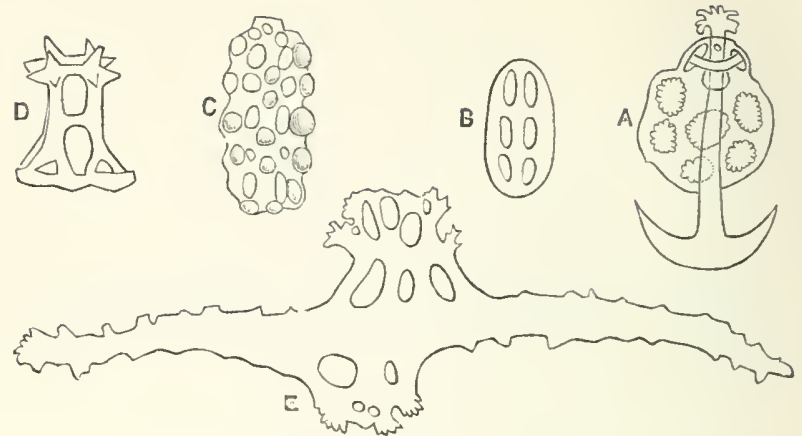

1. Anchor and plate of Synapta. B, C. Tables of Holothuria impatiens; and D. Holothuria atra: from rarious aspects. E. Spicule from sucker of Stichopus variegatus. (Magnified about 200 diam.).

Fig. 35.

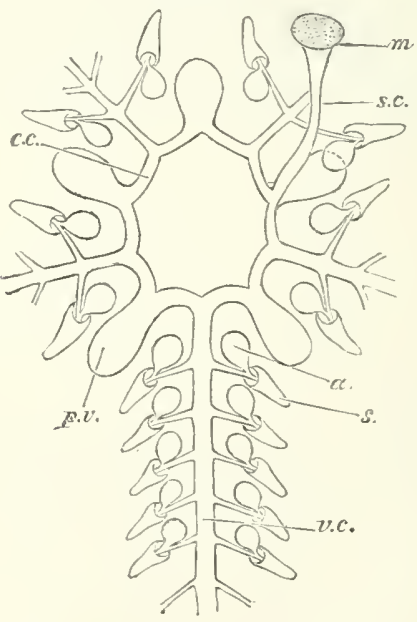

Diagram of Water-ressels.

cc. Circular canal, with p.ev, its Polian resicles; firom it a radial canal (v.c.) is giren off along the lower surface of each arm; this supplies, by side branches, the suckers, $s$; comnected with each sucker is a contractile strelling or ampulla $(a)$. The circular canal is in comnection with the exterior by s.c, the stone-canal, and opens to it by the madreporite ( $m$ ). 


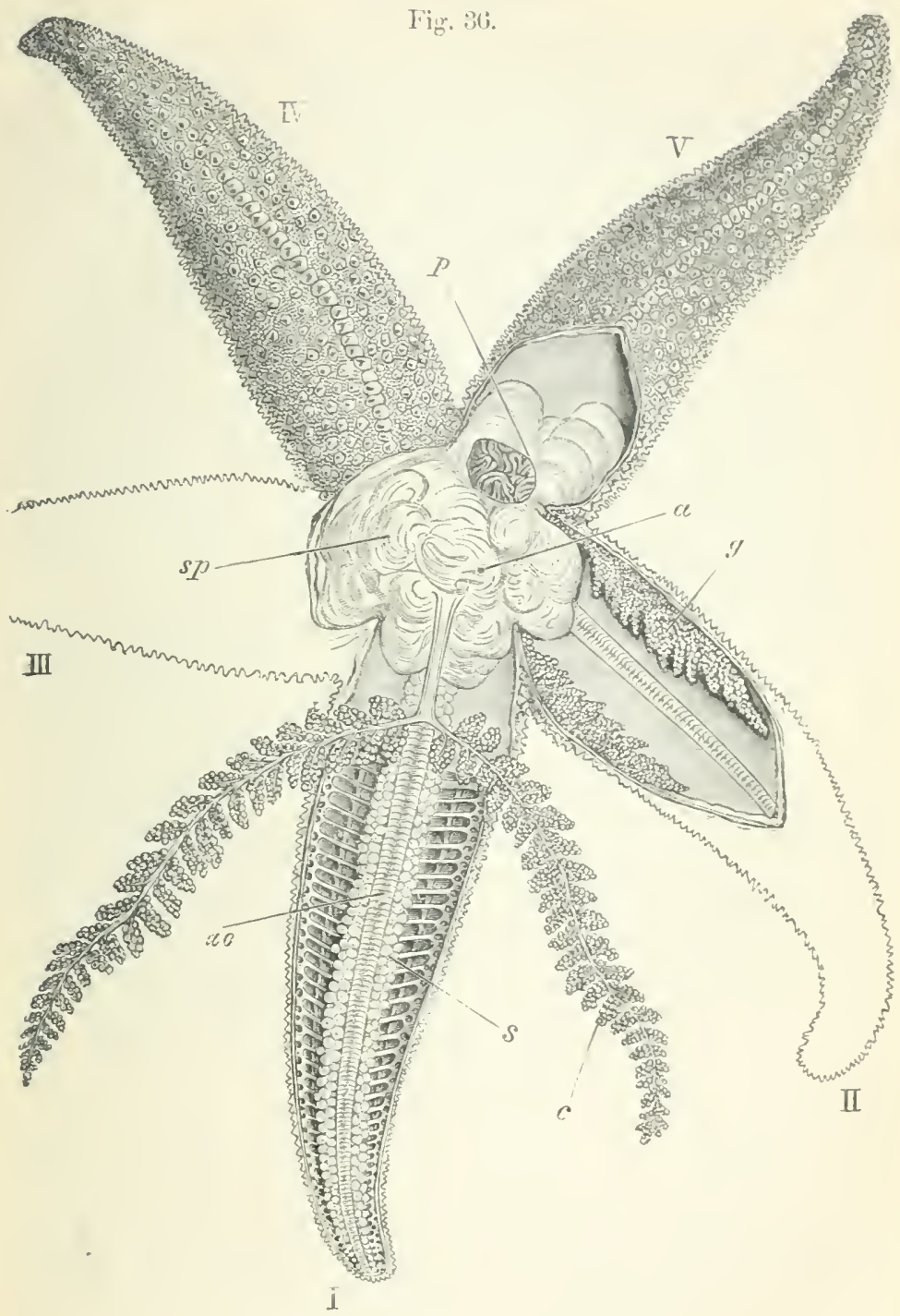

Figure of a Starfish (Asterias" rubens).

In the ray marked I. the skin has been remored from the upper surface, ant? the ambulacral ossicles (ao) and the sucliers (s) are scen in situ: the blind ontgrowths $(c)$ from the central stomach $(s p)$ liave been dissected out. In II. the gonads $(g)$ are exrosed; and in $Y$, the pouch-like direrticulum $(p)$ of the siomach is to be seen (where it joins the central stomach its roof has been remored to show the fulded arrangement of its walls). The anus $(\alpha)$ is seen to be subcentral in position. 
In the body of the Starfish (fig. 36) the arms are seen to be continuous witly the disk and to eontain portions or prolongations of the chief organs. The middle of the arm is occupied by two rows of hard pieces (ambulacral ossieles), the fellows of which make an open angle with each other, and so form an open ambulacral groore; along this we find the suckers, the water-canal that supplies them, the blood-vessel of the arm, and a nerve-cord. At the centre of the disk is the mouth. The ossicles at the sides of the arms bear spines, which vary in different species; the surface of the back is supported by a netrork of hard pieces, and through the intervening spaces there project membranons pouches, which are respiratory in function. The modified plate on the upper surface opens into a tube by means of which the water-ressels communicate with the exterior; this plate is known as the madreporite (fig. $35, \mathrm{~m}$ ).

The organs for masticating the food are most highly developed in the regular Echinoids, where the complex apparatus known as the "Lantern of Aristotle" is found (Case 7 D) to consist of five sets of pieces; the tooth is strong and bevelied at its free end ; it is supported by triangular jaws on either side, a pair uniting and having the form of an inverted pyramid; these alveoli are connected with their neighbours by oblong pieces (faices); above these there are elongated bars, which are hinged on to the inner end of the falces and have their onter ends free. The whole lantern is conneeted to the test by muscles which pass from its sides to the auricles or upstanding pillars which lie round the mouth; and, owing to this muscular apparatus, the teeth are capable of complicated and various movements.

In the Ophimroids the edges of the month-slits are provided with short spinous processes, varying a good deal in arrangement, but never having, apparently, any other function than that of a filteringapparatus; in the Starfishes the plates round the mouth have a supporting function only; in Crinoids and Holothurians the mouth is nnarmed; the latter are often remarkable for a deposit of calcareous plates in the walls of the gullet, and in the former the groove on the arm is the line along which food comes to the mouth.

Echinoids live on seaweeds and the animals that are found on them; such as have no teeth, like Spatangus (Case 6 E), use their 
spout-like mouth to take up the sand and débris on which they move, and from which they extract some nutriment. Ophiuroids live on the smaller Foraminifera; Asteroids on dead fishes (as linefishermen well know), Oysters, and other Mollusks, and even on specimens of their own particular species; Holothurians on shell or coral débris and the minuteorgamisms it contains; and Crinoids on small tests of Foraminifera and on the adults of small and larve of larger Crustacca.

In a number of Echinoids and Asteroids some of the spines are specially modified to act as seizing-organs-the free end being divided into two, threc, or rarely four picees, which are moved on one another by special muscles. These minute organs were regarded by earlier observers as parasites, and were named pedicellarice; they may be movable, when they have a stalk, or the stalk may be absent and the valves sessile. Considerable difficulty attaches to the determination of the usc that these organs may be to their possessors; but there is reason to suppose that they may act as cleansing-organs, by removing minute prarticles of dirt, and as temporary organs of fixation.

Echinoderms move but little; the unstalked Crinoids, if they cannot find stones or worm-tubes around which to attach themselves, swim by beating the water with their delicate arns, five being raised and five depressed alternately. The Echinoid or Asteroid is able to move by the aid of its suckers or so-called ambulacral feet, which become erected by being filled with water, and are then contracted; by means of this contraction morement is effected; a similar kind of locomotion obtains with the pedate Holothurians; in the Ophiuroids the flexible arms either serve as the organs of movement, or act as an apparatus whereby the creature becomes coiled round the branches of corals (sec Case $4 \mathrm{D}$ ).

Echinoderms are often of excecdingly bright colours, and are very conspicuous objects; this may, apparently, be associated with disagreeable tastes or odours; sometimes they corer themselves over with seaweed, and so hide their brilliancy; the spines of some forms are exceedingly painful to the touch, and the stout plates of some of the Goniasters must form admirable organs of protection. The power of restoring lost or injured parts is one of the most remarkable points in the Echinoderm organization. 
Echinoderms are of great geological age, and were very abundant in earlier periods of the world's history. Two groups (the Blastoids and Cystids) have completely disappeared, and the Stalked Crinoids (Lily-Encrinites) are far less common than they used to be. Echinoderms are now found in all seas, and extend to great depths of ocean ; many of the species have exceedingly wide areas of distribution, and most are characterized by their gregarious habits, a large number of specimens of a single species being generally obtained by the dredge. They are most abundant in the tropical seas.

Most Echinoderms lay thcir eggs in the water, where the larvæ are developed and swim about freely; but in a few (Hemiaster, Ophiacantha vivipara, and others) the young do not pass through any metamorphosis, the eggrs being received in special pouches of the body of the parent, in which they are hatched. The free-

Fig. 37.

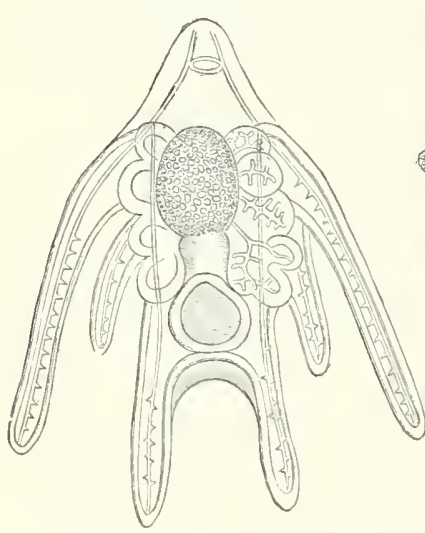

Developing larvæ.
Fig. 38.

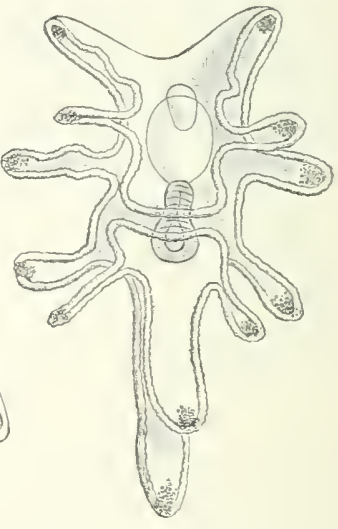

Fig. 38. Bipinnaria.

swimming larvæ of the other Echinoderms pass through a series of remarkable changes (figs. 37 and 38); these are illustrated by the twelve models of various forms of larve exhibited in Case $7 \mathrm{~B}$; in Case $7 \mathrm{~A}$ is a set of models showing in detail the changes uudergone by a single species (Asterina gibbosa). A portion only of the 
body of the larva is converted into the substance of the perfect animal; the rest is either absorbed by the rrowing animal, or shrivels up and disappears.

Below the twelve models in Case 13 may be scen a representation

1i... 39.

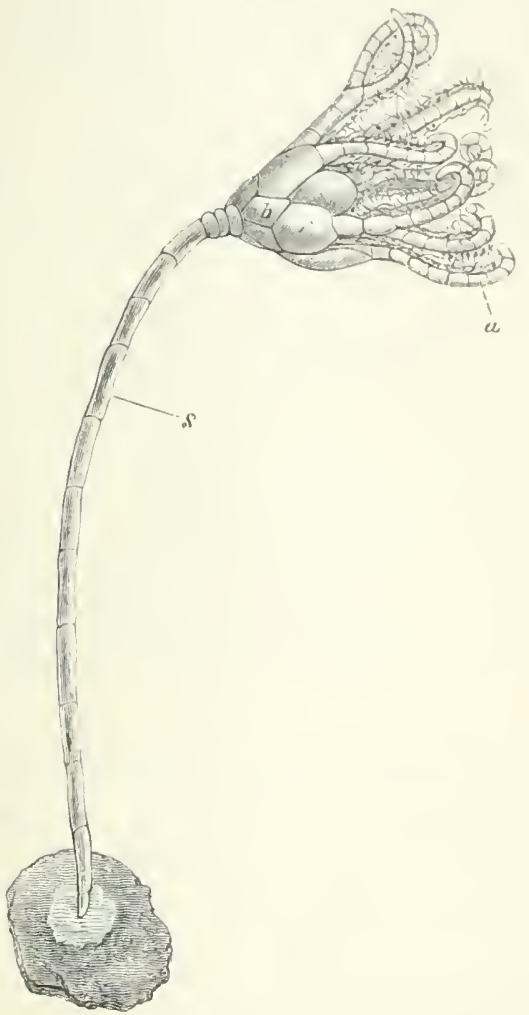

Pentacrinoid stage of Antedun resacea. $a$, arms ; $b$, basals ; $r$, radials ; $s$, stalk.

of three stages in the history of the Feather-star (Antedon rosacen). The larvæ of this Echinoderm are not free, but are attached by a stalk; in the common Feather-star and other Comatulide the stalk is found during larval stages only ; in others, such as P'entacrime, it persists throughout life. 
The presence or absence of this stalk nay be taken as the first character of importance in the classification of Echinodermata, which may be divided into two groups:-

A. PelinatozoA *, or Echinoderms provided with a stalk thronghout life or in the larral stages only. To this group belong the Crinoidea, and the extinct Blastoider and Cystidea.

B. EchisozoA, or Echinoderms without stalks at any time of their existence. To this group belong the Asteroidea, Opiniuroidea, Echinoidea, and Holothurioidea.

To understand the differences between these various orders it is well to become acquainted with the structure of the parts that form the base of the cup in Pentacrimus or the disk in Antedon.

The diagrams and preparations in Case $7 \mathrm{c}$ show that the primitive composition of the disk is a central plate, around which are two sets of five plate's each; five of these lie along the line of the arms or rays, and are radial plates, and five are interradial, or, as they are often called, basal; in Autedon the top of the stem, which is found in the larval stage only, fuses with this central plate, while the basals cease to appear on the surface; in Eclimus, or the SeaUrehins, the central plate is absorbed, while the bounding-plates retain their primitive relations; in the Starfishes and Brittle-stars the plates are less conspicuous, and in the Sea-Slugs they disappear altogether.

Crivordea.-This Order may be described as stalked, globular, or cup-shaped Echinoderms, in which the oral surface of the calyx or disk looks upwards, and in which five jointed and generally branched rays arise from the eentral disk. Their joints have jointed pinnules at their sides, and the sucking-feet have the form of tentacles.

The stalked representatives of this Order are placed on two tables in the corners by Case 7 , and are worthy of being particularly noticed for their fine preservation, size, and beauty. The largest specinen of Pentacrinus decorus was taken on a telegraph-wire, to the covering of which the stalk of the Crinoid is still attacherl. Metacrimus is a lately discovered genus, which appears to be confined to the eastern seas.

* From the Greek pelma $=a$ stalk. 
A few dried unstalked Crinoids are shown in Table-case l.1, and some preserved in spirit in 1 all-case $1 \mathrm{~V}$.; these show the leading modifications of structure in the two great gencra Antedun and Actinometra.

Asterondes.-This Order comprises Echinoderms with a depressed body of pentagonal or star-like shape, to the rentral surface of which the ambulacral feet are confined. The rays are more or less elongate movable arms, with skeletal structures, which consist of transwersely arranged, paired, calcareous plates, articulated with each other like vertebre, the series extending from the mouth to the end of the arms. The groore in which the ambulacral feet are arranged is uncovered.

Typical specimens of this Order are exhibited in Case 1 , in which the great variety of form in the genus Asterias and beautiful examples of Acontluster are shown. Case 2 в \& с contains specimens illustrating the curious habit of self-mutilation possessed by so many Echinoderms; among Starfishes, and notably in the genus Linckin, the single arms separated from the disk are able to

Figr. 40.

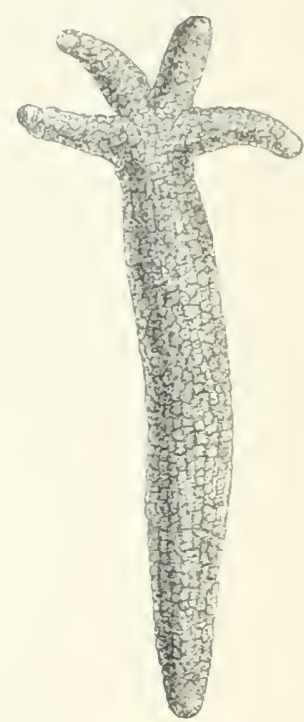

Comet form of Linchis. derelop a fresh disk and arms, and so to multiply the species. Cases $2 \mathrm{D}-\mathrm{F}$ and 3 a contain fine scries of Oreaster.

Ophiurordfa, or "Brittle-stars." - These Echinoderms appear to resemble the ordinary Starfish; but they differ in having the organs of digestion, respiration, and reproduction cunfined to the disk, the arms having merely the function of locomotive organs. The arms therefore are more slender and cylindrical in form, and are sharply distinct from the disk; the separate joints consist of two central ossicles, which leave only a narrow canal between them, and these are covered abore, below, and at the sides by specially developed investing plates; the lateral plates bear spines, which 
are always comparatively short and delicate, as compared with the spines found at the sides of the groove in Starfishes.

The principal types of this Order are exhibited in Case 4; the most exquisite of them are the forms whose arms are divided and subdivided till they end at last in the finest threads, as in Astroplyyton, the so-called Basket-fish or Gorgon's heads.

Ecinxorded, or "Sea-Urchins," are Echinoderms in which the rays are not free, as in the Starfishes or Brittle-stars, but unite to form a compact, spherical, heart- or disk-shaped test; this test is covered with spines, which may attain to a great length, as is shown in the fine example of Dicdema setosum fiom the Andaman Islands; some of the tests are flexible and very fragile; the form shown by a drawing in Case $5 \mathrm{c}$ will be seen preserved in spirit in Wall-case IV. Owing to the quantity of specimens that are sometimes dredged at one spot, the naturaiist has been able to gain a better idea of the range of variation in the species of Echinoderms than in some other divisions of the Animal Kingdom; an instructive series, showing the variations of Echinometra lucunter, is shown in Case $6 \mathrm{~A}$.

The enenus Hemiuster offer's an example of an Echinoderm in which the eggs are laid in special ponches; the hinder ambulacia are deepened to form pits, which are gruarded by specially elongated spines (see Case $6 \mathrm{~F}$ ) ; in these pits the young pass through all the stages of their development.

'The Holotnurionda, or Sea-Cucumbers, form the last order' of Echinoderms. Their body, as indicated by their English name, is elongate, subcylindrical, with a more or less flexible integument, according to the cxtent of the reduction of the calcareous sheleton; the mouth is at one end of the body and surrounded by tentacles, the vent at the opposite end.

As these animals camnot be shown in a dried state, some of them, preserved in spirit, are placed in Wall-case $I V$. According as they have or liave not the sucking-feet of the Echinodermata, they are ordinarily divided into the Pedata and the Apoda; the latter are represented by Synapta, which may attain to a great length, and by Chiroulota; the Pedata are illustrated by the genera Cucumaria, Psolus, and Holothuria. The deep-sea inrestigations of the last 
few years have revealed the existenee of another group of specially modified Holothurians-the Elasipoda; these are remarkable for their well-marked bilateral symmetry and the distinctness between the dorsal and ventral portions of the body ; the prominent processes on the dorsal surface are not contractile.

An exhibition of some interest is to be found in a Table-case against the wall, in which there are varions specimens of the celible Holothurians-trepang or béche-de-mer; these were all bought in the market at Canton, and may be taken to be typical of the kinds offered for sale in varions eastern countries.

\section{VERMES. (Worms.)}

Under the head of Vermes (Worms) zoologists are in the haibit, at present, of placing a number of different forms whose relations with one another are by no means so close as those of a Holothurian and a Crinoid, or a Mussel and an Oetopus; there are not any common characters by the possession of which the nembers of this group ean at once be distinguished from other animals. We must therefore take separately the divisions, examples of which are here represented, either by drawings, models, or specimens preserved in spirit.

Platyhelminthes, or Flat-Worms. - These form the lowest and simplest division of the group.

The parasitic Platyhelminthes-the Tapeworms (Cestoda) and the Flukes (Trematoda)—occupy Case I.; the life-history of the common Tapeworm (Trenia solium) is shown by the aid of models and figures. A model of the anterior end of the common 'T'apeworm shows the four suckers and the erown of hooks; the $1111-$ jointed neck is followed by the joints (proglottids), which increase in size the further they are from the neck. Several entire specimens of Tenia follow, showing the size of the whole worm and the form of its joints. The strueture of the body is shown in the models of two joints. The growth and development of the Tapeworm is dependent on a migration or a change of the hosts which it inhabits in the various stages of its life; and although the different kinds of Tapeworm differ from each other somewhat in certain details of their migration and development, their life-history exhibits, on the whole, the same events which we find in Trenia 
solium, the common Tapeworm of man in Northern Enrope. This worm is matured in the intestines of man; its final joints consist merely of fertilized ova which have already passed through the eariier stages of development; when the joints are detached and discharged, their contents escape in the form of embryos contained in a thick chitinons: shell. If these are now swallowed by a pig, the shell is digested by the gastric juices of the new host, and a rounded embryo, which is provided with three pairs of hooks, is set free; by means of these hooks the guest makes its way through the wall of the stomach or intestine, and finally settles down in the muscles of its host. The embryo now loses its hooks, and gradually acquires a bladder-like for'm, the central carity of which is filled with fluid. This bladderworm (Cysticercus) has its outer wall pushed inwards at the anterior end, and on this hooks and snckers become dereloped. We have now a narrow head and neck with an attached bladder, the head being at this time hollow. If during the long time that these bladder-worms remain alive, the pig is killed for food, its flesh is found to be "measly"; if it is afterwards insufficiently cooked and eaten, the worms are conveyed into the human stomach. Here the bladder-like termination becomes absorbed, and, the

Fig. 41.

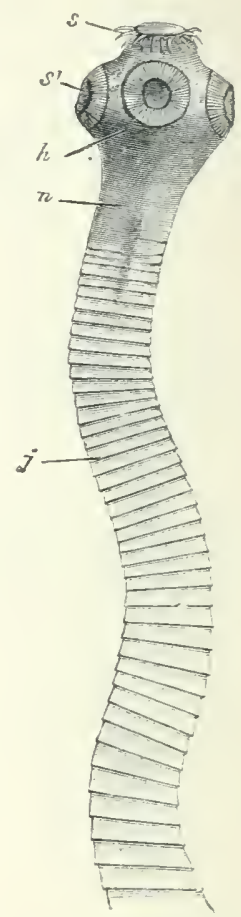

Tenic solium: showing the head $(h)$ with its sucker's $\left(s^{\prime}\right)$ and crown of hook: $(s)$, the unjointed neck (n), and a few of the succeeding joints (j). neck begimning to grow, we have the commencement of the form from which we started, and the completion of that "vicious circle" which is so curions a characteristic of many forms of parasitic life.

In other Tapeworms the cyst may be more complicated than that in the pig, as, for example, the form found in the sheep's brain or the liver of the horse. 
Of the other Cestode parasites we mention here specially those of Fishes, as the vulgar notion that the parasites of these animals are dangerous to man has been shown to be entirely erroneous.

The Flukes infest animals of all kinds; that which is most dangerous to sheep, and the cause of much pecuniary loss (Jistoma hepaticum), is selected here as a type; its structure is shown by a large model, and its life-history by a series of diagrams (figs. 4346). Here, again, we have a creature which infests two hosts. When the larva escape from the sheep they make their way to a small pond-snail (Limncea truncatula, fig. $4: 2)$, into the lung-chamber of which they bore their way. On leaving them the larva may be, and is too frequently, eaten by a sheep, and makes Iimnce truncatula. its way into the liver of that animal, where it causes the discase known as the "lot."

The damage done by the liver-fluke may be imagined from the fact that in the winter of 1879-80 no less than three millions of sheep died of rot in the United Kingdom; this heary loss is no doubt largely due to the immense number of eggrs to which a single fiuke may give rise. It has been estimated that every fluke may produce, during its life, several thousands of eggs; and in one case Prof. A. P'. Thomas found as many as $7,4.00,000 \mathrm{eggs}$ in the gall-bladder of a sheep which was suffering from rot, which, at that time, had in its liver about 200 flukes.

The simple non-parasitic Worms are shown, magnified, in the upper parts of Cases I. \& II. The Turbellaria proper, without any or with a simple or a branched intestine, but without a rent, are represented by Convoluta and Thysanozvon: the general structure is shown by a diagram in Case II., which is here reproduced (fig. 47). Planaria, Thysanozoon, and Bipalium serve to illustrate the forms of members of this group. 'The simple Worms (Nemertinea) with a straight intestime, with a vent, and witl a proboscis may attain to a very considerable length; Corinella and Lineus are represented by large figures, and various species are shown in spirit. 'These forms are, on the whole, very unsatisfactory to exhibit, on aceount of the great difficulty of preserving them complete and minjured.

Nematodes (Thread-Worms or Round-Worms).-These arc for the most part parasitic, and infest plants as wcll as animals; the 
Fig. 43.

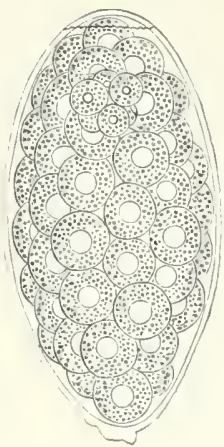

Fig. 45 .

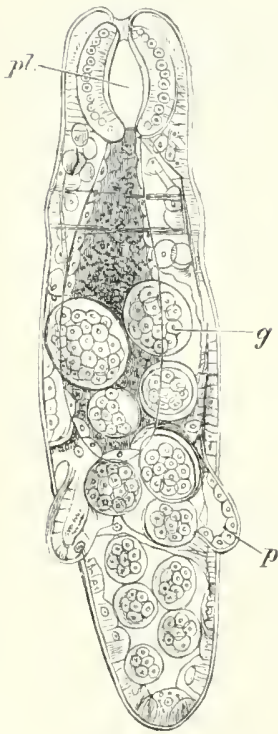

Fig. 44.

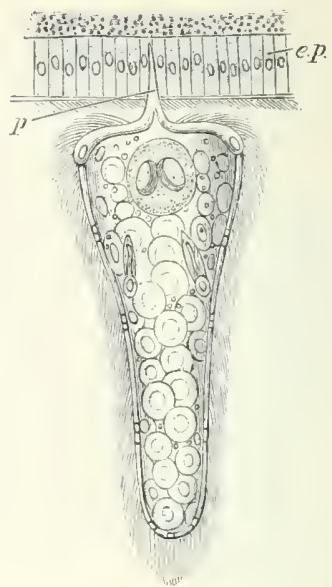

Fig. 46.

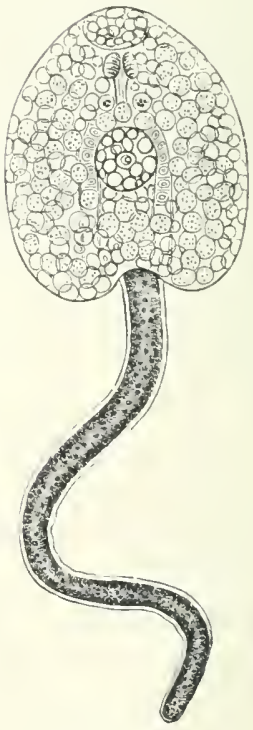

Stages in the life-history of the Fluke.

Fig. 43. Egg of Fluke, slowing the operculum and the contained yolkspheres. Magnified :340 diams.

Fig. 44. An embryo forcing its way by its boring-papilla $(p)$ into the wall of the lung of a Snail (e.p). Magnified about 340 diams.

Fig. 45. A young Rédia (watural size, $\frac{1}{2}$ millimetre or $\frac{1}{50}$ inch) : $p l$, pharrnx; $g$, contained germs; $p$, characteristic posterior processes of the Rédlia.

Fig. 46. Free-swimming Cercarin, before the commencement of the formation of the cyst. Magnified 100 diams. 
conmon Round-IVorms living parasitically in man (Ascaris, Slrongylus, Trichocephalus) belong to this Order. Sometines they are parasitic in their early stages and later live a frec life-such are

Fig. 47 .

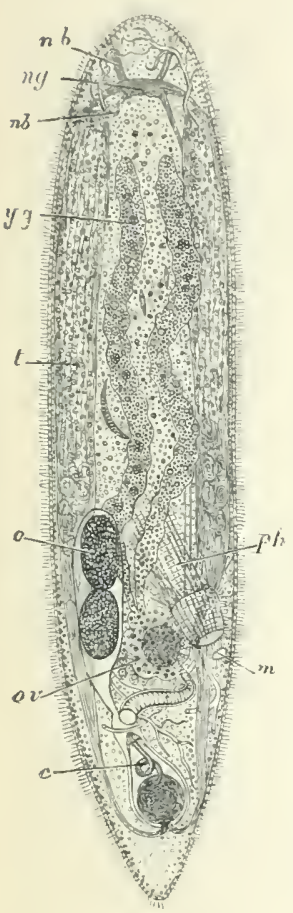

Fin. $f$.

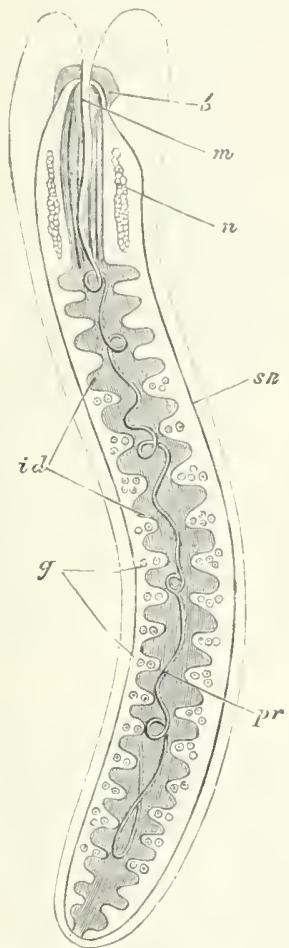

Fin. $4 !$.

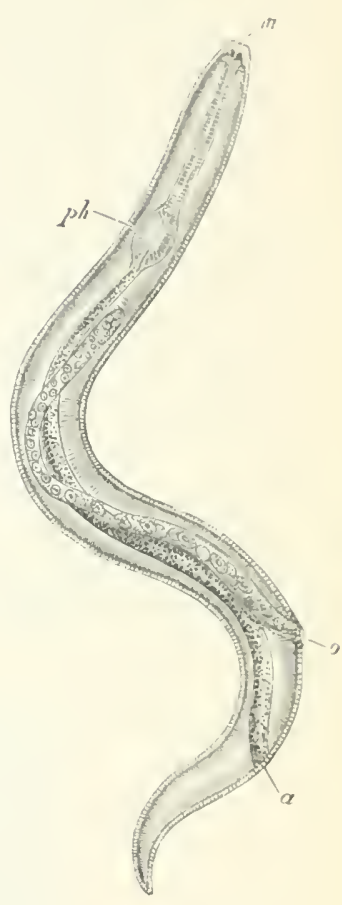

Fig. 47. Diagram of the structure of a Turbellarian: ny, nerve- (cerebral) ganglia; $n b$, nerve-branches ; $y$, yolk-glands ; $t$, testis ; $o$, ova ; $o v$, ovary ; $c$, cirrus ; $m$, mouth ; ph, pharyux.

Fig. 48. Diagram of a Nemertine : $b$, brain: $m$, mouth ; $n$, renal organs ; $i d$, diverticula of intestine; $y$, gouads; $s n$, sille nerve-trunk; $m$, proboscis in its dorsal sheatl.

Fig. 49. Diagram of the structure of a Nematoid: $m$, mouth ; ph, pharynx; $\iota$, anus; o, orifice of genital tube.

Gordius and Mermis. A specimen of a Mantid is cxhibited from which half the body of the infesting Gordius has already protruded (fig. 50). One of the most remarkable Gordii is the great elongated G. fulyur, or "Lightning Snake," from Celebes. Another very large 
Nematode is the so-called Guinea-worm, or Dracunculus medinensis, which is found beneath the skin of the leg; it is rery possible that

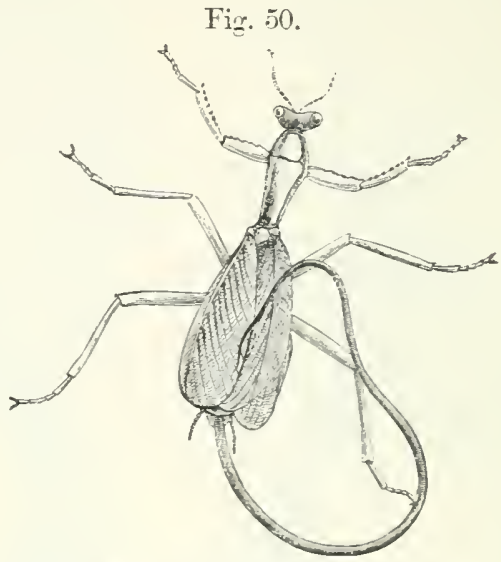

Gordius escaping from a Mantid.

this worm was the cause of the illness which afflicted the Israelites in their journey through the desert from Egypt to the Promised Iand.

Fi⿳⺈. 51.

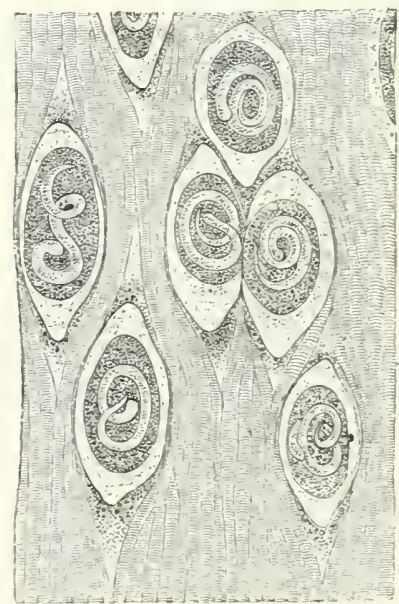

Figure of Trichina spriralis, showing the worms encrsted in nuscle.

Of all Nenatodes the most dangerous to man is the small worm 
which is known as Trichinn spiralis (tig. 51 ); a series of models are shown which grive a good idea of the structure of the female and the smaller male. The young make their way through the walls of the stomach of their host, and encyst themselves among its autscles: a piece of a stemothyroid muscle is shown, taken from a man in whose body it is calculated there were forty millions of encysted Trichina.

Other Nematodes infesting man, such as Filuria sanguinis hominis, are too small for exhibition.

Plants are not free from the attacks of Nematodes, and examples are shown, accompanied by an illustrating figure, of the Ear-cockle gall of wheat, the gall being due to the injuries inflicted by a minute Thread-worm-Tylenchus tritici. Wheat is, of course, by no means the only cultivated plant that is attacked by these mimute worms; the history of most has, however, still to be made ont.

Holding a somewhat uncertain position in relation to the Round. worms are the parasitic Acanthocephali (Thor'u-headed Worms) and the free-swimming Chatognatha, or Bristle-jawed Worms; exanıles of both of these groups are shown, together with diagrams illustrative of their general strueture.

Axvulata.-The creatures that are most familiarly called worms are to be found in Case III. ; here are a few examples of the numerous kinds of worms that are found living freely in the sea, of earth- and freshwater Worms, and of the Leeehes. All these worms are distincly characterized by the fact that they consist of a number of definite rings (somites), whence they have been called Annulata. The marine Worm and the Earthworm differ from the Leech in that these rings are provided with setæo or bristles, of which there are a number in each bundle in the marine, and a few ouly in the terrestrial or fresh water form: hence the marine Worms are called Polychceta and the latter Oligocheta.

The former are divisible nuto two great groups. There are those that are free-swimming and are able to forage for themselves, such as the lovely Sea-mouse (Aphrodite aculeata), the larige Eunce gigantea, the common Nereis pelayica, or the exquisitely coloured Chloeia flava. Others live a more retired life, dwelling in tubes, which they fashion for themselves; they lead either a solitary or a social life. Here we have examples of Subella, sabellaria, Ser- 
pulc; a number of forms of worm-tubes, showing their great variety and beanty (see especially the delieate Filograna), are to be seen in the small Table-eases placed against the north wall of the Gallery. Specimens preserved in spirit and illustrative diagrams will make plain to the student the relation between the worm and the tube it has formed.

The Oligochreta are represented by the eommon Earthworm, the influence of which in the formation of mould and in the general ploughing of the soil has been so earefully investigated by $\mathrm{Mr}$. Darwin; and by the little Tubifex rivulorum (Bloodworm), which owes both its red colour and its ability to dwell in mud, which is so poor in oxygen as to be unfit for respiration, to the same chemical compound as that which gives the red colour to our blood and carries the oxygen of respiration all over the body ; the preparation in the Case shows the creatures in their tubes in the mud.

The Hirudinea, or Leeches, are distinguished from the Chatopoda by the absence of bristles; they always have a sucker at the binder end of the body, and the mode of life is always more or less parasitic, though they are external, not internal; they are attached to their prey by their hinder sucker; they are found in fresh water (Piscicola), on sea-fishes (as Pontobdella), or they live in moist places, as the Leeeh (Hirudo). The last-named has three jaws, armed with as many as ninety denticles. Trochetia subriridis (Land-Leeeh) is a speeies which is found rarely and sporadieally in England.

The last group of Worms here represented is that of the Gephyrea; with the advanee of our knowledge it is probable that they will be found to be more intimately allied to the Anmulata than is now generally supposed. It will be seen indeed that Echiurus has bristles at its hinder end; Sipunculus is the best known representative of the unarmed Gephyrea; Bonellia is interesting both from the fact that it owes its green colour to a matter closely resembling the chlorophyll of green plants, and from the possession by the female of a proboscis, which is protruded from the hole in the rock oceupied by the worm; the male is very much smaller than the female, and is not nearly so well developed. 


\section{INDES.}

Acanthaster, 61 .

Acanthocephali, (i).

Achatina, 5 .

Acmaidae, 25.

Actinometra, 61 .

Etheria, 40.

Etheriidæ, 40.

Ampullarida, 19.

Ancylus, 31 .

Amiulata, 69,70 .

Anomia anigmatica, 46.

Anomiidæ, 46 .

Antedon, (i), (i). rosicea, 59.

Aphrodite aculeata, 69. Aplrsia, 1, 5.

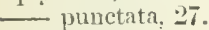

Aplrsiidae, 27.

Apple-Suails, 19.

Apoda, 6:2.

Area tortuosa, 41 .

Architeuthis harresi, 10.

Arcidx, 41.

Argonauta, $7,9,10$.

Arks, 8, 41 .

Ascaris, 67.

Asiphonida, \&, 33, 40.

Astartidæ, 39.

Asterias, $(i 1$. rubens, 55 .

Asterina gibbosa, 5 .

Asteroidea, 57, 60, (il.

Astrophiton, 52 .

Atlanta, $8,2 ?$.

Atlantidæ, 29).

"Auger-shells," 16.

Auriculidie, 31.

Aricula, 11 .

Ariculidæ, +1 .
Barbatia, 4].

Birtlettia, 41).

Basket-fish, 62.

Basommatophora, $S$.

Batissa. 34.

Biche-de-mer, (i3.)

Bipalium, (i.j.

Bipinnarit. 5s.

Bivalves, 3:"

Bladder-morm, fit.

Blastoidea, is, 60 .

Bloodworm, 7).

Boat-shells, 1 s.

Tonellia, 70.

Borer, $30^{\circ}$.

Brachiopoda. 47, 48.

Brechites, 37. raginiferum, 80 .

Bristle-jawed 11 orms, 69 ? Brittle-stars, 60, (il, (i2.

Bubble-shells, $4,8,27$.

Buccinidx, 11 .

Buccinum, 16. undatmm, 17.

Bulimi, 5.

Bullide, 27 .

Calamaries, $t$.

Calyptraidar, "21.

Cardiidie, 35.

Cardium edule, 3.5.

Carinaria, 8, 2!\%.

Carinella, 6io.

Caroueshells, $7,19,2 \cdot 2$.

Cassiditie, Is

Cassis, 1A.

Carolina, $\mathbf{i}$. tridentata, 13.

Cepplalopoda, $\bar{T}, \mathrm{~S}$.

Cerithiidx, : 0 .
Cestode parasiles. (i;

Chatognatba, 1i!).

Chatropuda. 7().

Chama, 3i).

Chirodota, (i).

Chiton. 1, 4, 7, 25. 2(1). clegans. 201;

Cbitomellus, $2 \pi$.

Chitonidae. 25.

Chiton squamosus, :2(i.

Chlocia llava, (iy).

Clanis, :35.

Clam-shells, -

Clio, 7 .

- borealis, $1 t$.

Coat-of-mail shells, $1,2.5$, 26 i

Cockle, 1, 2, 8, 33, 3.5, 41.

Comatulida, 5i,

"Conchologists." ".?

Cones, 7, 15, 16.

Coms gloria-nuaris. 1.i.

Conroluta, (iii).

Corbieula, 34.

Corbiculiclax. :H

Corbulidax. 39.

Cowries, 19, 20.

Crania, 47, 48.

Crepridula, 21 .

Criuoids, $\bar{i}(;, 5,5$, (i), iil.

Crucibulum, 21.

Cryptiscluiton, 2 -

Cuculliva, 41.

Cucuuaria. 6:2.

Cup-and-sancer Limpet: $\stackrel{-1 .}{1}$

Cuttlefisl, 1, 4. Ћ. 10, 11 .

Cychophosida, 20 . 
Cymba, 18.

Crmbium, 18.

Crmbulia. 1, 7.

Cyrrea aurora, 20.

- europrea. :0.

- moneta, 20 .

-- tigris, 19.

Cspratidre, 19.

Cirena, 34.

Crsticercus, 64.

Cystidea, 58, 60.

Cytherea lusoria, 34 .

Decapoda, 7 .

Dentaliidæ, 32.

Dentalium, 1,8.

— pretiosum, 3:2.

-_. tarentinum, 32 .

Desert-Snail, 6.

Diadema setosum, 62.

Dibranchiata, 7,9

Dipsas plicata, 4 .

Distoma hepaticum, 65 .

Doliicix, 18.

Doris, 5,8 .

Doto coronata, 29.

Dracuneulus medinensis. (i).

Duck's-bill Lingula, $\$ 8$.

Ear-cockle gall, 69.

Ear-shells, 7. 2:3.

Earthwolms, 199, 70 .

Echinodermata, 5.3.

Echinoidea. 50, 57. 60 , (i).

Echinometra lucunter, (i⿱2).

Echinozoa, 60 .

Echinus, (in.

Echiurus, 70.

Elasiporla. fi.

Elephant Tooth-shell, 2.

Eolis. 5.

Ennice gigantea, 69.

Enribia, 7 .

False Limpets, \&, 25.

Fan-Mussel, 42.

Fan-shells. 44

Fasciolaria gigantea, 17 .

Fasciolariide. iT.

Feather-star, 5?.

Ficula, 1s

Fig-shells. 1s

Filaria sanguiuis hominis. 69

Filograna. 70.

Firolas, s.

Fisirnellida, 203.
Flat-worms, $(33$.

Flukes, 63, 65, 66.

Fonntain-shell, 22.

Fresluwater Limpets, 31.

- Mussels, 5, 40, 44 .

- Snails, 4, 30. Worms, 69.

Gapers, 8, 39.

Gastropoda, 7, \&, 14.

Gephryea, 70 .

Giant Clam, 6, 35.

Glassy Nautilus, 29.

"Glory-of-the-Sea" Cone, 15.

Goniastel 157.

Gordius, 67,68 . fulgur, 67.

Gorgon's head, 62.

Guinea-worm, 68.

Grmnosomata, 7,14 .

Haliotidx. 23.

Haliotis, 23.

Hammer Orster, 41, 43.

Harp-shells, 7, 17.

Helicidæ, 30.

Helicinide. 20.

Helix desertorum, 6. pomatia, 30 .

Helmet-shells, ]s, 2.2.

Hemiaster, 58, 6?.

Heterojods, 29.

Hirudinea, 70 .

Hirudo, 70 .

Holotburia, 6?.

- atra, 54 .

- impatiens, it.

Holothurioidea, $56,5 \bar{T}$, $60,62,63$.

Ianthinæ, 1S.

Kerhole Limpets, 22,26 .

Kuphus arenaria, 37.

Lamellibranchiata, 3 .

Lamp-shells, 47 .

Land Leech, 70 . Snails, 4, 5, 6, 80 .

Leeches, 6!), 70 .

Lightning Snake, 67.

Lilv-Encrinites, .8 .

Lima, 45 .

Limacidie. 30.

Limacina, 7 .

Limnæ1, 5.

_- stagnalis. 31 .

- trumeatula, 6.5.

Limnæidæ, 2, 30, 31, 32.
Limpet, 1, 2, 7, 22, 23, $24,25,26,32$.

Iimpet-like Snails, 30 .

Limpet-Snails, 32.

Linckia. 61.

Lineus, 65.

Lingula anatina, 48 .

Lithodomus dactylus, $\downarrow 1$.

Littorina littorea, 20 .

Littorinidx, 20 .

Lirer-fluke, 6.5.

Loligo rulgaris, .5.

Lucapina crenulata, 25.

Lucinidx, 39.

Mactra solidissima, 35 .

Mactridæ, 34 .

Magilus, 16.

Malleus, 43.

Iargaritana margaritifera, 40.

Marine worms, 69.

Melaniidæ, 20 .

Meleagrina margaritifera. $42,+3$.

"Melons," 18.

Mermis, fit.

Metacrinus, 60 .

"Mineralogists," 22.

Mitra. 17.

Mitridxe, 17.

Molluscoida. 47.

Moner-cowry, 20 .

Tiileria, 40 .

Murex brandaris, 16 .

Mnnices, 16, 18.

Mussel, 3, \&, 40, 11 .

Inussels (freshwater), 5, 40,44 .

Mya arenaria, 39 .

- truncata, 39.

Mvidie. 39.

Mrtilidae, 40.

Mrtilus edulis, 41.

Naked-gilled Mollusks, 29.

Natice. 5, 18.

Sautilide, 7 .

Yautilus, 2, 3, 6, 8, 9, 12, 13.

- - pompilius, 12.

Taricellas, 2.2.

Nematodes, (i.), (i., 68 , 60.

Nemertinea, 6i. 67.

Yereis pelagica, (6!)

Terites, 2. $7,2.20$.

Neritiuas, 2:2.

Non-parasitic Worms, (i.J. 
Nucleobranchiatu, 8, 14, l'illolocks, E, :3i, 3i. oy.

Nudibranchiata, $8,27,28$.

Oetopodia. 7 .

Oetopus, 1. 2, 7, 8, 9, 10. rulgaris, 9.

Oligochreta, 19,70 .

Olives, $7,1 \%$.

Ommatostreples, 3,9 .

Uncidium, 4.

Onustidx, 20?.

Onustus, 2:2.

Ophiacantha vivipara, os.

Ophiuroidea, $51 \%, 57$, (iu. (i).

Opisthobranchiata, $t, \&$, 14. 27.

Orange Cowry, 20.

Oreaster, fil.

Ormers, 23.

Ortlioceras, $\mathbf{6}$.

Ostrea edulis, 45 . gigas, $\$ 6$. virgnniea, \pm 6 .

Ostreidx, 45.

Orulidix. 19.

Oyster, 1, 3, 5, 6, 8, 33, $40,45, \pm 6$.

Paludina, 1 . rivipara, 21 .

Palndiniclie. 21.

Paper-Nautilus, 8, 9.

Patella compressa, 25.

—_ mexicana, 25 - mytilina, 25 - rulgata, 24, 25

Patellx, 25.

Pearl-Oyster, 8, 41, t2, 43.

Pearly Nautilus, 7, \&, 9, 12.

Pecten, 3,44 , 45.

Pectinibranchiata, 7 .

Pectinidae. 4 .

Pectmenlus, 41 .

Pedata, 6i:.

Pelecrpoda, 3, 8, 33 .

Pelmatozon, 60.

Pentacrinus, 59. decorus, $\mathbf{6 0}$.

Periwinkle, 7. 20, 21.

Perspectire-shells, 18.

Pholadiclie, 36,37 .

Pholas daetylus, 36.

Phoridre, 19.

Pliorus, 2.2.

Phvllirhoë, 3.

Phissa, 5.
Pimma, $4 \mathrm{l}, 43$.

pretimata, 42.

Piseicula, 70.

Pisidium, 34.

Placunidie, 40 .

Plamaria, (i.).

Platylelminthes, 63 .

Plenrotomal. 11 .

Plenrotomatidie, lid.

Pluteus, ¿2.

Polvelucta, 69.

Polyplacophora, 7 .

Polyzon, 47.

Pond-Musiel, (i.

Pond-Smils, 2, 31

Ponfobdella, 70.

Poulp, 7 .

Prosobranchiata, $\bar{i}$, It, 15.

Psolus, (i-).

Pterocera, 20).

Pteropola, $7,13,14$.

Pulmunates, $8,14,20$, 30.

Pupillea aperta, 2.5.

"Purples," 16.

Purpura, 16.

Radius rolva, 19.

Razor-shells, 2, \&, 33, 38.

Rhyuchonella, 48.

River-Ilussels, 5, 8.

River-Snails, 21 .

Rock-Limpet. 24, 25, 32.

Rock-shells, 16.

Rock-Snails, 7 .

Round-worms, 67, 69 .

Sabella, 69.

Sabellaria, 69.

Saddle-Orsters, fi,

Sealaria pretiosi, 18.

Scalariidie, 18.

Scallops, s, 33, 38, $44,45$.

Seapharca, 41 .

Scipphopoda. 8, :32.

Scorpion-shells, 2.2.

Screw-shells, :2)

Scutibrancliata, $\bar{T}$.

Sea-Butterflics, ]:.

Sea-Cucumbers, $5 \%$, (i2.

Sen-Haje, 1, \&. ㄴ.

sea-Lennons, s.

Sen-mouse, 1i?.

Seatslugs, 4 , .3. 100

Sen- L"rchins, 53. $(90,62$.

Sea-IToudlice, 25 .

semele, 34.
Sepia, $3,9,10$.

- otlicinatis, 9, 11.

Serpula, 21, lis.

Ship-woru, :37.

Siplonnaria, 8̈.'.

Sipllomariike, $30,83: 2$.

siphonida, \&, :33, üt.

Sipuneulus, 7 \%)

slipper-Limpet - 2l.

Slit Limpets, "2:".

"slit-lips." 11.

Slug, 1, 2., $8,30,31,32$.

Snail, 1, 2. 8, 20, 30, 32.

solarium, 1s.

Solenidie, 로 3 .

Solens, :is.

solen siliqua, 38.

spatanuus, 56.

Spharium, 34.

Spider-claws, 2:2.

Spirula, $8,9,11,12$.

- peronii, 11.

Spondylidx. $4 t$.

Squid, I, 5, 7, $2,9,11$.

Stalked Crinoids. 5, 60?.

Starfishes, 5i, 55, 50, (i), $61,09$.

Stichopus rariegntus, 54.

Strombidre, 7, 21, 22.).

Strombus gigas, …)

Strongrlus, tit.

Strlominatophora, 8 .

Synapta, 54, li2.

Tienia, f:?.

- - solimm, 1.4.

Tit peworm, 63, lit.

Tretibranchiata, 8.

Tellens, 8, 34 .

Terebritula, $\pm \overline{7}, 43$.

Terebrida, 11;.

T'eredinidx, 37.

'Teredo norregica, 37.

Testaeella, :31

Tetrabranchiata, $7, ?$.

Thecalia conemerata, 40 .

Theeosomate. 7. 13.

Thorn-headed Worms, 19.

Thorny Oysters, tt.

Thread-worms, (ii), (i9.

Thysinozoon, (i.i.

Tiger Cowry, 1!!.

Tooth-shell: \&, 32.

Top-shells, $\tau, 23$.

Trematoda, 1 i3.

Trepang, (i:3.

Triclini spiralis, fit, 69.

Trichina, get. 
Triehocephalus, $6 \overline{7}$.

Tridacna elongata, 36. - - gigas. 35,36 .

Tridacnæ, 36.

Tridacnide, 35.

Trigonia, 2, 41.

Trigoniidæ, 41.

Triton variegatus, 18.

Tritonidie, 18.

Trochetia subviridis, 70 .

Trochidie, 22.

Trumpet-shells, 18.

Tunicata, 4i.

Tun-shells, 1s.

Turbellaria, 65, 6it.

Tubifex rivulorum, 70 .

Turbinicle, 20.2.

Turbo petholatus, 23.
Turbos, 2.

Turritella consmunis, 21.

Turritellidx, $: 0$ ).

Tylenchus tritici, 69.

Umbrella mediterranea, 28.

Umbrella-shelis, 8, 27,28 .

Unio, 40.

Unionidæ, 40 .

Telorita, 34.

Veneridæ, 34, 40.

Venus mereenaria, 34.

- rermcosa, 34 .

Tenus-shells, 33.

Termes, 63.

Termetidæ, 21.
Violet Snails, 18

"Volutes," 18.

Water-Clams, 44.

Trateringpot-shells, 8, 37,3 s.

Water Snails, 8 .

- Spondyli, 4.

Wearer's-shuttle, 19.

Wedge-shells, 8 .

Wentle-traps, 18.

Whelk, $1,5,7,16,17$.

Window-shells, 46 .

Wing-shells, $7,21,41$.

Winkles, 2.2.

Worms, 53, 63 .

Worm-shells, 21 .

Worm-tubes, 70 . 
4i British luseur. (intural Kistom) 406 Dept. OI Eolo Ej

Eof. Guice to the shell and

IESC stiritish ocileries

Eiolied 
